Quality Management Journal

\title{
ISO 14001 standard: Literature review and theory-based research agenda
}

\begin{tabular}{|r|l|}
\hline Journal: & Quality Management Journal \\
\hline Manuscript ID & UQMJ-2018-0031.R1 \\
\hline Manuscript Type: & Review Article \\
\hline Keywords: & ISO 14001, environmental sustainability, systematic literature review \\
\hline Abstract: & $\begin{array}{l}\text { Environmental sustainability has gained momentum in the business world } \\
\text { and academia. After about twenty years of research in this field, this paper } \\
\text { presents an holistic literature review specifically focused on ISO 14001, } \\
\text { which is widely considered the most important environmental certification. } \\
\text { analyse systematically the scientific debate in this field. We identify six } \\
\text { streams of ISO 14001 research, i.e., drivers, barriers, tools and methods, } \\
\text { impact on performances, enabling factors affecting adoption and } \\
\text { performances. We then summarize these research streams and highlight } \\
\text { conflicting results and unexplored research areas. Finally, we propose a } \\
\text { theory based research agenda. }\end{array}$ \\
\hline
\end{tabular}




\title{
ISO 14001 standard: Literature review and theory-based research agenda
}

\begin{abstract}
Environmental sustainability has gained momentum in the business world and academia. After about twenty years of research in this field, this paper presents an holistic literature review specifically focused on ISO 14001, which is widely considered the most important environmental certification. We apply an antecedentsprocess-consequences framework in order to analyse systematically the scientific debate in this field. We identify six streams of ISO 14001 research, i.e., drivers, barriers, tools and methods, impact on performances, enabling factors affecting adoption and performances. We then summarize these research streams and highlight conflicting results and unexplored research areas. Finally, we propose a theory based research agenda.
\end{abstract}

Keywords: ISO 14001, environmental sustainability, systematic literature review

\section{Introduction}

Environmental sustainability has become a key priority for managers, scholars and policy makers (McKinsey 2013; Walker et al. 2014; Lee and Klassen 2008, European Commission 2014). Several environmental management systems (EMS) and certifications have been created as a way to control companies' environmental impact and encourage the spread of green practices (e.g., ISO 14001, EMAS, Carbon Trust Standard, FSC, and MCERTS).

ISO 14001 - issued by the International Organization for Standardization in 1996 is nowadays the most popular environmental certification (e.g., Delmas and Montes-Sancho 2011; Aravind and Christmann 2011). During the last decade the number of certified 
companies has increased constantly ( $23 \%$ average annual growth), leading to more than 300,000 certified companies in 2017 (ISO, 2018).

The breakdown of ISO 14001 certified companies by industry and country is

presented in Table 1 and 2. These tables show that the certification is spread across a very wide set of industries (primary, secondary and tertiary) and counties (more than 170 in all the continents). The most important industries are not surpringly construction $(18.63 \%)$ and manufacturing, in particular metal products $(9.48 \%)$, electrical and optical equipment $(9.30 \%)$, machinery and equipment $(5.88 \%)$, rubber and plastic products $(5.11 \%)$, and chemical products $(4.25 \%)$. As far as the distribution by country is concerned, the importance of China (45.69\%) and more in general of the East Asia and Pacific region (almost $60 \%$ of the total number of certified companies) is of particular interest. Companies from these countries feel probably a prominent need to show their environmental commitment, in particular to Western customers. On the other hand, Europe is also an important country for the ISO 14001 certification (about 30\%), in particular UK, Italy, Spain and Germany. Not many American firms seek instead to obtain the ISO 14001 certification. This might perhaps be due to the already cogent and well-structured environmental laws and regulations of the country, which entail a significant set of mandatory activities in this field.

The steady rise in the ISO 14001 adoption has drawn the attention of many researchers who have studied a wide set of topics, including motivations for companies to pursue this certification (e.g., Bansal and Bogner 2002; Vastag 2004), problems faced during its adoption and management (e.g., Alberti et al. 2000; Vastag and Melnyk 2002), and effects on firm performance (e.g., De Jong, Paulraj, and Blome 2014; Melnyk, Sroufe, and Calantone 2003a; Paulraj and de Jong 2011). 
Despite the primary importance of the ISO 14001 certification for both managers and scholars, previous literature reviews had a wide focus, such as green supply chain management (e.g., Srivastava 2007; Molina-Azorín et al. 2009; Sarkis, Zhuand, and Lai 2011; Fahimnia, Sarkis, and Davarzani 2015) and environmental sustainability (e.g., Marchet, Melacini, and Perotti 2014). Some literature reviews analysed ISO 14001 together with other standards, mainly ISO 9001 (e.g., Heras-Saizarbitoria, Landín, and MolinaArzorín 2011; Boiral 2013), paying limited attention to this environmental standard. The review developed by Tarí, Molina-Azorín, and Heras (2012), for instance, analyzed only 29 papers on ISO 14001; most of the authors' efforts were focused on the analysis of IS0 9001 literature.

Almost all the aforementioned literature reviews do not consider papers published after 2012, even if the annual number of scientific contributions was relevant after this date. The only exception is rapresented by the paper published by Boiral et al. (2017) that considered contributions published until 2015. This paper, however, it's mainly focused on the impacts of ISO 14001 and the obstacoles/contingent factors that may influence the succesfull adoption of the standard. Moreover this work does not provide a depening of the most adopted theories; therefore a theory based research agenda is also missing.

Consequently an holistic and updated map of the research on ISO 14001 is still absent. It is useful to review the main research trends in this field, to highlight conflicting results and unexplored research areas, to understand the most important theoretical lenses adopted in this research field.

Therefore, we identified, selected, and summarised existing papers on ISO 14001. We (1) analysed the distribution of the papers in relation to geographical focus and 
underpinning theories, (2) identified gaps and conflicting results in the literature, and (3) suggested a theory based research agenda.

In this way, we offer a contribution to theory and practice. From an academic point of view, we review a field that no other authors have approached in an holistic way so far, therefore contributing to an advancement of the maturity level in the field. From a practitioner standpoint, our literature review may help managers to leverage more effectively the academic knowledge to take more aware decisions concerning this certification.

The remainder of the paper is structured as follows. First, we describe the approach adopted for reviewing the literature. Second, we present the descriptive findings of the review and provide a thematic analysis of the findings. Finally, we draw some conclusions from the review in order to provide an agenda for future studies.

\section{Approach to the literature review}

In order to ensure rigour, objectivity, and transparency in the research process, we adopted a systematic literature review approach to obtain replicable and valid results (Rousseau, Manning, and Denyer 2008; Tranfield et al. 2003; Radziwill, 2013; Thomé et al. 2016). First, we defined the criteria for including papers in our review. We restricted our literature review to contributions published in peer-reviewed English-language scientific journals, as often done in previous studies. Furthermore, since our goal was to identify articles of indisputable quality, we decided to focus on the two highest-grade journals (i.e., 4 and 3) according to the Association of Business Schools' (ABS) Academic Journal Guide (Harvey et al. 2015). The quality of the journal is indeed frequently considered as a proxy for the 
quality of its papers (e.g., Gosling and Naim 2009; Lightfoot, Baines, and Smart 2013;

Müller, Pemsel, and Shao. 2014; Evans, Foster, and Linderman 2014). Furthermore,

the ABS list is widely recognized as a good indicator of journal rigor and quality (Johnsen

2009; Miemczyk, Johnsen, and Macquet 2012) since it is based not only on citations

metrics (such as the Scimago Journal Rank [SJR] or the Impact Factor) but also on the

assessments performed by leading scholars in each research field. A methodological

approach similar to ours was adopted in some previous literature reviews (e.g., Pallaro et al. 2015; Müller, Pemsel, and Shao. 2014).

We performed a keyword search on two of the most important electronic databases, i.e., Elsevier's Scopus and Thomson Reuters Web of Science ${ }^{1}$, to identify any relevant contribution meeting the criteria described above. We used the "ISO140*" OR "ISO 140*" search string, as the asterisk allowed us to consider both the general ISO 14000 series of standards and the specific ISO 14001 standard. We further examined the reference lists of the identified papers to spot any additional contribution missing in the initial selection (i.e., “snowball sampling” approach). In total 125 papers were identified.

Finally, we read the full text of the papers and excluded 38 of them because they only mention the ISO 14001 certification without providing any significant analysis and result related to it. The final analysed sample consists therefore of 87 papers.

The coding and analysis process followed an inductive-deductive approach. Categories were defined a priori by drawing from other literature reviews on similar topics (e.g., ISO 9001 and SA8000 certifications) and by our research experience (deductive approach). Such categories have been adjusted during the analysis, considering the themes

\footnotetext{
${ }^{1}$ Considering that all journals of grade 3 and 4 of the Association of Business Schools' (ABS) Academic Journal Guide are indexed in one or in both databases, the use of other electronic databases or search engines (e.g., Google Scholar) would not have changed the final results of our search.
} 
emerging from the articles (inductive approach). The papers were first classified according to: author, year, journal title, research purpose, methodology, unit of analysis, sample dimension, headquarter country/countries, underpinning theories, industry, company size, and research topics (see Appendix). We then codified the ISO 14001 research topics following the antecedents - process - consequences framework by Narayanan, Zane, and Kemmerer (2011): the antecedents section consists of drivers/barriers/enabling factors related to the adoption of ISO 14001; the process section summarizes the tools and approaches connected to the certification process; and the consequences section focuses on the effects of ISO 14001 on firm performances and their enabling factors (see Figure 1). Finally, we developed a detailed table for each research topic, which frames and summarizes the main findings (see Table 4-5-6-7-8-9).

[Insert Figure 1 about here]

To enhance the reliability of the results (Duriau, Reger, and Pfarrer 2007), three researchers conducted the coding and analysis process independently. A few cases of disagreement or different evaluation among the three coders were jointly discussed until agreement was reached.

\section{Descriptive findings}

In this section, we present the general trends coming to light from our literature review. These comprise: the distribution of the publications over time, their publication outlets, the geographic areas of the studies, and the theories used. 
The first article included in our review was published in 1997, one year after the introduction of the ISO 14001 standard. During the following years (2000-2017), an average of 4.8 contributions per year were made, with a peak of 11 papers in 2012 .

Reviewed papers were published in a wide set of journals belonging to different disciplines, including operations management, business ethics, economics, innovation, strategic management and general management. OM journals account for about $50 \%$ of the reviewed papers.

From a geographical point of view, the majority of articles refer to the American continent (27), followed by Asia (20) and Europe (17), only four studies focus on Oceania. This distribution partially reflects the global spread of the standard (ISO, 2015). Despite the international dimension of ISO 14001 and the possible influence of country-specific socioenvironmental factors, only nine papers adopt a cross-country approach focusing on Europe, the USA and Asia (e.g., Johnstone and Labonne 2008; Bansal and Bogner 2002). This indicates the need for future studies to adopt a cross-country approach in order to extend the results of previous research and evaluate the influence of different geographical and cultural aspects.

About one third of the reviewed studies (28 papers, approx. 33\%) is theorygrounded. Literature reviews in the closely related field of sustainable supply chain management (Carter and Easton, 2011; Touboulic and Walker, 2015) present similar percentages. Table 3 provides an overview of the main concepts of these theories and their application in ISO 14001 studies.

[Insert Table 3 about here] The table highlights that a wide spectrum of theories have been adopted so far. The Institutional and Neo-Institutional theories (Selznick 1957; DiMaggio and Powell 1983) 
have been the most frequently applied (16 articles). These theories provide a useful framework for analysing the behaviour of a company facing various pressures from the environment. Another theory frequently embraced is the Resource Based View (Barney 1991) (7 articles), as various authors argue that ISO 14001 could be seen as an intangible resource (e.g., Delmas 2001; Schoenherr 2012). Finally, the Stakeholder Theory (Freeman 1984) is a further lens used to explain the diffusion of ISO 14001 ( 3 articles). As emerged in some recent literature reviews (e.g., Sartor et al. 2016), this theory has been extensively adopted until now also for dealing with ISO 9001 and SA8000.

\section{Thematic findings}

In this section, the main research topics of ISO14001 literature are presented with particular attention to the most important or conflicting findings. A set of tables is also enclosed to provide the reader with detailed information about each theme of analysis (see Tables $4,5,6,7,8,9)$.

\subsection{Antecedents}

\subsubsection{Drivers}

The drivers that may encourage companies to seek ISO 14001 certification have been examined by 36 amongst the reviewed papers. Table 4 summarizes the drivers and classifies them according to the source (Internal vs. External) and type (Economic, Environmental, or Hybrid).

[Insert Table 4 about here]

Among the most cited drivers, there is the desire to improve a company's image (Internal-Economic, 20 papers). The certification is seen as a source of competitive 
advantage, improving the company's external perception (e.g., King, Lenox, and Terlaak 2005; Viadiu et al. 2006) and exerting a positive effect on public opinion (Orsato 2006).

In some studies (e.g., Hsu et al. 2013; Zhu et al. 2012b), ethical reasons related to the environmental sensitivity of the company's management have also been reported (Internal-Environmental, 8 papers). Melnyk, Sroufe, and Calantone (2003b) argue that companies often perceive the certification as "the right thing to do", without expecting an economic return in the short term. These ethical reasons seem to prevail at the beginning of the certification process (González-Benito and González-Benito 2005).

Several studies (e.g., Teixeira 2012; Alberti et al. 2000) suggest that firms seek ISO 14001 certification in response to pressure by customers (External-Hybrid, 24 papers). This pressure usually derives from larger business clients who play an important role in the supply chain (González, Sarkis, and Adenso-Diaz 2008). For instance, corporations like Ford, General Motors and Toyota asked to their key suppliers to get this certification (Orsato 2006).

Some authors (e.g., Jiang and Bansal 2003; Montiel, Husted, Christmann 2012) argue that ISO 14001 is perceived by companies as a useful tool (in particular in international relations) to reduce information asymmetries between suppliers and buyers (Internal-Hybrid, 4 papers). Companies seek this certification to avoid opportunistic behaviours by their suppliers (Montiel, Husted, Christmann 2012).

Another motivation that leads companies to obtain the ISO 14001 certification (e.g., Del Brío and Junquera 2003; Delmas and Toffel 2008) is the presence of environmental legal requirements (External-Environmental, 17papers). Companies are frequently pushed by regulatory bodies or governments to embrace management practices that ensure a sustainable exploitation of the environment (Miles, Munilla, and Russell 1997). This is 
particularly true in some industries, e.g., the chemical sector, in which environmental issues are critical, due to the intensive use of toxic materials (Alberti et al. 2000; Delmas and Montiel 2009). However, according to Johnstone and Labonne (2008), the use of ISO 14001 certification for compliance reasons makes more sense for larger companies (over 250 employees), which usually are more exposed to inspections.

Motivations to adopt ISO 14001 differ during the diffusion period (Baek 2017). Early adopters use ISO 14001 as a competitive resource; later adopters are more influenced by institutional pressure. As ISO 14001 spreads, it comes to be 'taken for granted'. Baek shows that firms' drivers for the adoption of ISO 14001 change as the program becomes widely recognized in the country. Additionally, the importance of motives seems to differ among business sectors (Tuppura et al. 2016) and countries (Neves, Salgado, and Beijo 2017).

\subsubsection{Barriers}

The barriers that may affect ISO 14001 have been discussed by 22 studies in our sample. We summarize these contributions in Table 5, classifying the barriers into three categories: those expected during the adoption of the certification, in the ongoing management, or in both these phases.

[Insert Table 5 about here]

An interesting barrier that emerges from the literature (e.g., Delmas 2001; Boiral 2011 ) is the risk of spreading confidential information (Adoption, 4 papers). In many cases, the management of the certification process is outsourced to consultants (Boiral 2011). This may lead to a risk of sharing sensitive information (ibid.). Long-term relationships with 
consultants as well as legal measures might be adopted to mitigate this risk (Zutshi and Sohal 2004a). However, the involvement of the same external consultants over time can initiate some dependencies (Boiral 2011).

Another important barrier is the expected reduction in productivity due to administrative tasks required (Ongoing Management, 3 papers). Certified companies have to archive and manage the documentation related to environmental impacts and actions taken to improve past performances (e.g., Bansal and Bogner 2002). This can lead to a high level of bureaucratization and the need for dedicated resources (Boiral 2011). In many cases, companies underestimate the efforts for administrative actions necessary for the ongoing management of the certification (Zutshi and Sohal 2004b).

Some studies (e.g., Montie et al. 2012; Del Brío and Junquera 2003; Boiral 2011) argue that companies occasionally perform a formal (ineffective) implementation of ISO 14001 (Ongoing Management, 5 papers), i.e., they implement the certification primarily for its potential commercial value rather than for really improving business practices. Such a focus limits the efficacy of ISO 14001, in particular in its ongoing management (Boiral 2007; Ferrón-Vílchez 2016; Iatridis and Kesidou 2018).

The most debated barrier of ISO 14001 (e.g., Orsato 2006; Alberti et al. 2000) is the cost of certification (Both, 8 papers), defined by some authors as the "cost to be green" (e.g., Orsato 2006). This cost includes the work of the certification bodies, the time spent by the company in analysing their own processes, modifying them, developing the necessary documentation and training the personnel (Zutshi and Sohal 2004b). Besides the aforementioned initial certification costs, there is an annual cost for maintaining the certification (e.g., auditing and documentation management) (Bansal and Bogner 2002). 
These costs may represent a further obstacle to ISO14001, especially for small and medium enterprises (e.g., Orsato 2006).

Finally, another relevant barrier is the difficult outcome evaluation (e.g., Delmas 2001; Sullivan 2005) (Longitudinal, 4 papers). In particular, the lack of quantifiable benefits is a significant obstacle to actively pursue the certification (Vastag and Melnyk 2002). Companies driven mainly by economic motivations can see the benefits of ISO 14001 as particularly uncertain (Melnyk, Sroufe, and Calantone 2003b).

\subsubsection{Enabling factors affecting the ISO 14001 adoption}

A significant number of studies have focused on the variables that may facilitate the adoption of ISO 14001 (38 papers). The role of these variables is to reinforce the drivers' effect and/or to reduce the barriers' effect. We summarize this debate in Table 6, classifying them into firm-specific and contextual enabling factors.

[Insert Table 6 about here]

Some studies (e.g., Zutshi and Shoal 2004b; Viadiu et al. 2006) show that the presence of a previous environmental management system (EMS) is an enabling factor in the adoption of ISO 14001 since it tends to increase the likelihood to implement the certification (FirmSpecific Factor, 8 papers). The adoption of a standard/management system could simplify the implementation thanks to the experience gained and the possibility to share common activities (King and Lenox 2001). While most authors agree with this finding, Melnyk, Sroufe, and Calantone (2003b) present a conflicting result. These authors argue that while the new development of an EMS can be seen as an opportunity to become ISO 14001 certified, companies with consolidated EMS are more reluctant to get the certification because they are already internally aligned with environmental requirements. 
Some scholars (e.g., Alberti et al. 2000; González-Benito and González-Benito 2005; Nishitani 2008) assert that large companies are more likely to adopt the ISO 14001 certification (Firm-Specific Factor, 12 papers). The adoption of ISO 14001 requires investments in time and financial resources and SMEs may have greater difficulties in finding these resources (e.g., Miles, Munilla, and Russell 1997; Montiel and Husted 2009). According to Graafland and Smid (2016), SMEs prefer to use simple formal management tools in order to raise the quality of environmental management without incurring in high bureaucratic costs. Furthermore, larger companies can obtain the certification more quickly due to higher competences on average (Nakamura, Takahashi, and Vertinsky 2001). In the end, since their corporate marketing division can be more influential, large firms tend to emphasize more customers' requests of obtaining the certification (Delmas and Toffel 2008).

According to several studies (e.g., Corbett and Kirsch 2001; Jacobs, Singhal, and Subramanian 2010) there is a positive relation between a company's strategic proactivitydefined as the tendency to implement the most advanced and modern practices (GonzálezBenito and González-Benito 2008) - and the likelihood to implement ISO 14001 (Internal Factors, 9 papers). Under this perspective, the adoption of the certification might be considered as a proactive way of managing regulatory changes, community relations, and public opinion (Jiang and Bansal 2003).

More conflicting results have been obtained apropos contextual enabling factors.

Corbett and Kirsch (2001) find no effect from the economic development of headquarters' region. Vastag (2004) claims that in the most economically advanced countries there are greater chances to get certified due to a higher availability of skills and resources. Schoenherr (2012) shows that the certification is rather better accepted in 
emerging economies (e.g., China and Brazil) than in industrialized countries. He argues that this may happen due to the fact that industrialized countries have in many cases already reached their performance frontier (or are very close to it), therefore improvements are more difficult to obtain.

Husted, Montiel, and Christmann (2016) find that the local density of certifications among geographically proximate firms increases the likehood of obtaining ISO 14001 certification. In particular, the local density of certifications has a larger effect on domestic firm's certification decisions than on certification decisions of multinational enterprise subsidiaries.

Delmas and Montes Sancho (2011) highlight that a positive relationship exists between the ISO 9001 diffusion level in the country and the adoption of ISO 14001. Due to similarities between the two standards (also in their implementation paths), positive experiences with ISO 9001 could facilitate the adoption of ISO 14001. However, there are conflicting results in this instance as well. Melnyk, Sroufe, and Calantone (2003b) show that ISO 9001 certified plants are less likely to welcome the ISO 14001 certification. The authors provide two possible explanations for this result: (1) firms having difficulties with ISO 9001 or bad experience with the certification process are reluctant to start another audit and certification process; (2) ISO 9001 certified firm often have also an EMS and therefore do not necessitate to get ISO14001 certified.

\subsection{Process}

The literature devoted to tools and methods used with ISO 14001 is presented here and summarized in Table 7.

[Insert Table 7 about here] 
Many studies (29) (e.g., Corbett and Kirsch 2001; Schoenherr 2012; Texeira 2012) deal with the Plan-Do-Check-Act (PDCA) cycle role - explicitly mentioned by ISO 14001 that force to adopt a continuous improvement logic and fix increasing challenging (environmental) targets.

A relevant technique, discussed in 6 studies (e.g., Lo, Yeung, and Cheng 2012; Gonzàlez-Benito and Gonzàlez-Benito 2008), is Life Cycle Assessment (LCA), utilized for the evaluation of the environmental impacts associated with all stages of a product's life from cradle to grave. Literature highlights that LCA is useful to assess direct environmental impacts, but also indirect ones that are typically harder to be estimated. The technique allows companies to (re)design their products/processes in order to improve their practices. Some studies (e.g. Reynolds and Yuthas 2008; Zutshi and Sohal 2004a, 2004b) indicate that the use of some elements of Total Quality Management (TQM) (e.g., the "team-based" approach, the cross-functional integration, the enlargement of the employees' mansions) is effective in the ISO14001 implementation.

Five articles highlights the importance to activate a systematic communication with the stakeholders. Paulraj and De Jong (2011), for instance, show the convenience of a bidirectional communication with external stakeholders, focusing on the relevant elements and informing them about the activities already achieved. In addition, the use of information technology is an important tool to gain high implementation effectiveness (Ivanova, Gray, and Sinha 2014).

Among the techniques analysed in single studies, Nakashima, Nose, Kuriyama (2006) suggest the use of the Data Envelopment Analysis (DEA) in the evaluation of environmental performances. This method can be applied taking into consideration different inputs (e.g., trash quantity, $\mathrm{CO} 2$ gas emission) and outputs (e.g., total revenues) in 
order to determine the efficiency.

\subsection{Consequences}

\subsubsection{Impact on performance}

The performance impact of ISO 14001 is the most debated topic in the literature (49 papers). We summarize this research stream in Table 8 classifying the analysed performance dimensions according to the four perspectives of the Kaplan and Norton's (1992) balanced scorecard.

\section{[Insert Table 8 about here]}

Some authors (e.g., Alberti et al 2000; Boiral 2007) show that the adoption of ISO 14001 led to increased process productivity and control (Business Process Perspective, 9 papers). During the implementation process, employees working in various corporate functions are called to examine and improve their business processes. This usually leads to the achievement of better operational performance (Melnyk, Sroufe, and Calantone 2003a). Only one article (Schoenherr and Talluri 2013) presents that the certification has a negative effect on productivity. According to them, the implementation of the ISO 14001 certification requires time and often radical changes within the company. This causes a decrease in productivity (at least) in the short term, until the new procedures are assimilated. Another effect of the ISO 14001 certification highlighted by the reviewed studies (e.g., Zailani et al. 2012; Alberti et al. 2000) is a reduced waste and consumption of resources (Business Process Perspective, 14 papers). Lo, Yeung, and Cheng (2012), for instance, focus on fashion and textiles - which sometimes have a high level of emissions and argue that the adoption of ISO 14001 allow to reduce the pollution production and associated costs. Darnal and Kim (2012) show that all types of EMS (i.e., 14001-certified 
EMSs, complete noncertified EMSs, and incomplete EMSs) lead to a reduction of natural resources consumption, solid wastes, and global air pollutants.

According to He and Shen (2017), ISO 14001 certification improves company-wide practices of resource management, which enable firms to better invest their resources in R\&D and innovation activities.

Three studies analysed the efficacy of ISO 14001 on the firm's performance on the stock exchange (Financial Perspective). Paulraj and De Jong (2011) elucidate that the announcement of certification has a negative impact on the value of the shares, since it is perceived as misaligned with the typical short-medium term orientation of the shareholders. Jacobs, Singhal, and Subramanian (2010) underline that ISO 14001 leads to a long-term positive reaction of the financial markets. Shareholders perceive the certification as a signal of the company's commitment to align its processes with international best practices, and to improve environmental management as well as operational performance. This positive effect is more significant in those sectors in which the ISO 14001 certification is considered a prerequisite to operate (ibid.). Additionally, Xu et al. (2016) assert that firms that are ISO 14001 certified face a smaller decline in stock prices after environmental violation.

The impact of the certification on sales performance is still a debated issue (Financial Perspective, 9 papers). On the one hand, Jacobs, Singhal, and Subramanian (2010) claim that ISO 14001 could improve financial performance via the revenue gains from enhanced reputation. On the other hand, Link and Naveh (2006) find no correlation between environmental and sales performance.

Several contributions (e.g., Melnyk, Sroufe, and Calantone 2002; Orsato 2006) point out that the adoption of ISO 14001 leads to an improved corporate image and reputation (Customer Perspective, 10 papers). Great and Melnyk (2002) argue that certified 
companies are better accepted by external stakeholders (including customers) since they demonstrate more responsibility towards environmental issues.

Finally, many authors (e.g., Delmas 2001; Muskin 2000) highlight the positive impact of ISO 14001 on compliance with law/regulations (Learning and Growth Perspective, 12 papers). Certified firms tend to be compliant with all the relevant environmental regulations and are therefore less likely of being cited for violating them (McGuire 2014).

\subsubsection{Enabling factors affecting the performance}

Many studies (23 papers) have evaluated the factors that might facilitate the performance impact of ISO 14001. This debate is summarized in Table 9.

[Insert Table 9 about here]

Strategic coherence (i.e. the consistency between the certification goals, policies and actions) is the most frequently highlighted variable (7 papers) affecting the performance impact of ISO 14001. Delmas (2001) argues that the interests of shareholders should be aligned in the search of environmental sustainability. Boiral (2011) echoes that the firm should be able to define and effectively communicate: (1) why the standard should be adopted; (2) which could be the internal advantages; and (3) the relationship among advantages, mission and strategic goals of the organization.

Four studies show up a positive effect of top management commitment. An environmentally sensitive top management is able to influence the way in which the certification is adopted and results achieved.

Another enabling factor supporting the performance impact of ISO 14001 (3 papers) is the involvement of employees. Human resources should be aware of the requirements of 
the standard and its objectives, and should attend training programs on environmental issues (Boiral 2011). However, Kitazawa and Sarkis (2000) argue that, although training is of prominent importance, it is not always able to guarantee the required cultural change. To support and motivate employees, incentive mechanisms are welcome. Four studies (Paulraj and De Jong 2011; Schoenherr 2012; Ivanova, Gray, and Sinha 2014; Fryxell and Szeto 2002) stress that the impact of ISO 14001 may be contingent on company size. Paulraj and De Jong (2011) prove that the negative reaction of the financial market, which in some cases follows the announcement of the certification, is less significant for large companies. This is mainly due to the fact that large companies may more easily reassure investors that the decision to pursue the certification is the result of a careful analysis about costs and benefits, persuading them that the certification is the right strategic decision (ibid.). Schoenherr (2012) echoes that the effect of ISO 14001 on operational performance is higher for large companies. However, Ivanova, Gray, and Sinha (2014) note that the size of the company has not effects on the performances.

Delmas (2001) argues that stakeholders involvement (suppliers, customers, government agencies, and shareholders) can contribute to make the adoption of ISO 14001 more effective. Also Lee et al. (2015) state that, among the ISO 14001 certified firms, having green suppliers increase environmental performances and competitive advantage.

Literature also shows that the industrial sector in which the company operates moderates the performance impact of the certification (Vastag and Melnyk 2002). Companies belonging to the chemical sector tend to achieve, for instance, the best results due to the ISO 14001 adoption. On the contrary, companies competing in the machinery, electronic and electrical components industries obtain the worst results. This can be explained by the fact that in these sectors the short-term certification impact is less 
significant since improvements in the processes require a long-term redesign (ibid.).

Furthermore, Chiarini (2014) claims that manufacturing companies are not as confident as service companies about ISO 14001 to be an effective strategy for improving the environmental performance of the supply chain.

According to Arimura et al. (2016), the performance impact of certification is affected also by the type of environmental regulation in the home country. Infact, plants located in countries with stronger and more flexible environmental regulation can develop more creative and effective solutions.

Su et al. (2015) argue that also early ISO 14001 implementation timing relative to industry rivals positively affects firm performance. The performance benefits increase in a highly competitive environment, and also prior ISO 9001 experience moderates the relationship between the implementation timing and firm performance.

\section{Research agenda}

This systematic literature review of ISO 14001 certification has highlighted the main research trends and identified some conflicting results and unexplored research areas. We therefore conclude our study by elaborating an agenda for future research on ISO 14001 . This agenda is organized according to the framework adopted in the review, i.e., antecedents, process, and consequences, and summarized in Figure 2. We also show in our findings that little research draws on theory. Hence, our recommendations for future research also attempt to address this shortcoming.

[Insert Figure 2 about here]

\subsection{Future research avenues on antecedents}


Whilst the drivers of the certification have attracted considerable attention, there exist several potential avenues for future research that contribute to a better understanding of antecedents. The certification has been seen as a prerequisite to compete in certain markets (Alberti et al. 2000). However, the international dimension of the certification has not been analysed in a systematic way. None of the reviewed studies focuses for instance on the relationship between ISO 14001 and global sourcing. Extant operations management and international business research has analysed the internationalization process of companies' activities, highlighting some sequential evolutionary stages (e.g., Johanson and Wiedersheim-Paul 1975; Rajagopal and Bernard 1993; Hemerling and Lee 2007). Future ISO 14001 research could focus on the possible link among these evolutionary stages and the adoption and management of this certification. This may help show and understand possible interdependencies between internationalization phases and ISO 14001. As far as manufacturing internationalization is concerned, future research could study the relationship between the adoption of ISO 14001 and the four sequential stages highlighted by the Uppsala school, i.e., no regular export/import activities, using agents, establishing a foreign sales branch and establishing a production unit (Johanson and Wiedersheim-Paul 1975).

Future research on antecedents can also shed light on the motivational differences between large and small companies adopting ISO 14001. For example, it may be interesting to explore the role of firms' (inter-)dependence on the adoption of ISO14001. SMEs may feel pressured to adopt the certification in order to maintain a relationship with larger companies. On the contrary, large companies may adopt ISO 14001 independentely (e.g., visibility and reputational motivations). With a deeper understanding of these differences it is possible to further consider the role of institutional factors as well as inter-organisational 
aspects. Resource dependence theory would be a fruitful lens to adopt in this context. Other theories (e.g. contingency theory and signalling theory) may be useful to understand in which context organisations should adopt a certification like ISO 14001.

The topic of the certification barriers is the least studied aspect within antecedents.

Contributions in this area tend to focus on the cost of certification (e.g., Orsato 2006).

Recent studies on other barriers (e.g., the difficult outcome evaluation) are lacking. For these reasons, significant attention should be devoted to this research topic. In the same line, as one of our earlier suggestions, it would be interesting to understand the country specific effects on the barriers. This could be achieved by conducting comparative studies across different nations, hence offering a more international and contextually relevant perspective of barriers to certification. Such research would certainly provide major insights on the role of regulatory and industrial contexts in preventing the certification.

As far as enabling factors are concerned, it is worth recalling that research has found conflicting evidence regarding the role played by the previous implementation of an EMS on the adoption of ISO14001. In particular, it was shown that previous experience could either support or hinder the adoption of the certification. Given the lack of consensus on this topic, this is an interesting avenue to further explore. Theoretically, an organisational learning and/or a sense making perspective (Easterby-Smith 1990; Weick 1995 ) could help conceptualise the role of organisational previous experience on the decision to adopt ISO14001.

\subsection{Future research avenues on process}


There are three main avenues for future research around the implementation and diffusion of the certification. First, limited attention has been paid in exploring the implementation and diffusion aspects of ISO 14001 at the inter-organisational level. For instance, it would be possible to analyse the implementation and diffusion of ISO 14001 from an ecological modernisation theory (EMT). EMT would be a powerful lens not only to constitute the macro-level institutional and legal framework required for ISO 14001, but also to understand diffusion mechanisms and inter-organisational relationships between large buyers and small suppliers (Murphy and Gouldson 2000; Sarkis, Zhuand, and Lai 2011). By bringing attention to the inter-organisational level, researchers would also be able to explore the potential power mechanisms that may be at play in ISO 14001 implementation.

An additional shortcoming of current research on the ISO 14001 diffusion is the predominant focus on organisational level factors, with little consideration is given to micro behavioural aspects. A deeper understanding of the role of individuals in championing or hindering the adoption and diffusion of certification practices would be valuable in guiding managerial decisions and actions, in particular in order to ensure employee engagement. An understanding of the behavioural aspects of environmental practices has been already called for by some authors (e.g., Carter and Easton 2011; Pagell and Shevchenko 2014; Touboulic and Walker 2015).

Finally, as highlighted previously, Resource Dependence theory would be well suited to explore motivational aspects. It may also serve to enhance our understanding of how ISO 14001 may contribute in reducing information asymmetry (Sarkis, Zhuand, and Lai 2011; Simpson, Power, and D. Samson 2007) and in mitigating potential risks, especially when cultural distance may exist between trading partners. This could help 
enhance our understanding of the certficiation implementation and diffusion in an

international context.

\subsection{Future research avenues on consequences}

Impact on performance is the most debated topic, but also the research area with the most conflicting results. We found no agreement among authors on the effect of the certification on sales (e.g., Muskin 2000; Schoenherr and Talluri 2013) and on stock market performance (Paulraj and De Jong 2011; Jacobs, Singhal, and Subramanian 2010). Future research is therefore needed in this field. A possible framework that could be adopted is Kaplan and Norton's (1992) Balance Scorecard (BSC). It considers both short-term and long-term horizons and organizes the performance indicators into four prominent dimensions, i.e., business process, financial, customer, and learning and growth. Future research could examined the combined effects of ISO 14001 on all four dimensions, identifying possible interdependencies and trade-offs. Another theory that may be useful to study the overall value of the ISO 14001 certification is the Stakeholder Theory (Freeman, 1984). The basic assumption of this theory is that the company should identify those actors who can affect or be affected by its activities (i.e., the stakeholders) and shape its strategy to address their concerns. Three reviewed studies (González, Sarkis, and Adenso-Diaz 2008; Zailani et al. 2012; Testa et al. 2018) adopted stakeholder theory but only focused on a specific geographical area (i.e., Spain, Malaysia, and Europe). Scholars should therefore conduct more extensive and systematic analysis adopting this theory to shed light on how ISO 14001 contributes to meeting the interests of different stakeholders' groups in the short and long term. 
There may also be opportunities to consider performance measures more broadly in light of the three dimensions of sustainability (environmental, economic and social). In particular, it would be interesting to compare the achievements of ISO 14001 on some key measures of environmental sustainability with those of different certifications or EMS. Researchers could draw on recent studies which focused on performance metrics in green and sustainable supply chains (Ahi and Searcy 2015). Once again, information theory may help establish the mediating role of ISO 14001 certification on overall environmental performance. Some recent contributions (Matthews et al. 2016; Montabon, Pagell, and Wu 2016; Pagell and Shevchenko 2014) have also called for a more eco-centric perspective on sustainable SCM, emphasising the need to understand the true ecological impact of green SC practices. Research examining the performance impact of ISO14001 is well suited to respond to this call, and could potentially examine how, if at all, ISO14001 contributes to reducing companies' impact on planetary boundaries (Whiteman et al. 2013).

Finally, only four papers (Vastag and Melnyk 2002; Delmas 2001; Chiarini 2014; Arimura et al. 2016) have focused on contextual factors that can moderate the impact of the ISO 14001 certification on firm performance. There is therefore a need to deepen our understanding of the influence of contextual factors on the effectiveness of certification implementation. These contextual factors include the location of the company, the location of its main suppliers, the location and characteristics of its sales markets (e.g., perfect competition, oligopoly), industry (e.g., labour intensive vs. capital intensive), and product characteristics. A theoretical lens that might be embraced in this context is Contingency Theory (e.g., Burns and Stalker 1961; Donaldson 2001). This theory postulates that there is no an unique best way to manage an organization and that the best strategies and actions are contingent on a number of contextual factors, both internal and external to the firm. 


\section{Conclusions}

In this paper we presented an holistic literature review specifically focusing on ISO 14001. We applied an antecedents-process-consequences framework to organize the scientific debate in this field. We identified six streams of research on ISO14001, i.e., drivers, barriers, tools and methods, impact on performances, enabling factors affecting adoption and performances.

We highlighted the drivers that may encourage companies to seek the ISO 14001 certification and classified them according to the source (Internal vs. External) and type (Economic, Environmental, or Hybrid). We presented the barriers that may affect the ISO 14001 adoption and management, including, among the most cited, the procedural implementation, the cost of certification, the risk of spreading confidential information, and the difficulty of evaluating outcomes. We analysed the enabling factors affecting the certification adoption. We observed a high level of agreement between authors on the effects of firm-specific factors. We highlighted instead more conflicting results for the contextual factors affecting the adoption/diffusion of ISO 14001 such as the economic development of headquarters' region and the level of diffusion of ISO 9000 in the country. We noticed that the performance impact of ISO 14001 is the most debated topic in the literature and classified the analysed performance dimensions according to the four perspectives of the Kaplan and Norton's (1992) balanced scorecard. Finally, we observed that many studies have analysed the factors that might moderate the performance impact of the certification, such as the strategic coherence, the involvement of employees, and the company dimension. Some contradictory findings were underlined. 
This systematic review of ISO 14001 literature allowed us to identify a set of knowledge gaps and present a research agenda on the topic. Despite many years of academic interest in this field, several key questions remain still open. For instance, which is the nature of the relationship between the adoption of ISO 14001 and the stages of the internationalization process? Which role does ISO 14001 play in reducing information asymmetry in the supply chain? Which is the role of individuals (managers and employees) in supporting or hindering the implementation and diffusion of the certification? Which are the contextual factors that might moderate the impact of ISO 14001 on performance? Which are the effects of the certification on sales and stock market performance? All these questions are just a subset of potential avenues that could be explored in the future.

In sum, our study offers a contribution to theory and practice. From an academic standpoint, we review a field that no other authors did in such detailed way, enabling to advance the level of maturity in the field. From a practitioner point of view, our literature review may help managers to understand how organisations address their environmental responsibilities by means of ISO 14001. They can effectively make use of knowledge created by scholarly research in order to take more attentive decisions concerning this certification.

\section{REFERENCES}

Ahi, P., and C. Searcy. 2015. An analysis of metrics used to measure performance in green and sustainable supply chains. Journal of Cleaner Production 86: 360-377.

Alberti, M., L. Caini, A. Calabrese, and D. Rossi. 2000. Evaluation of the cost and benefits of an environmental management system. International Journal of Production Research 38 (17): 4455-4466. 
Aravind, D., and P. Christmann. 2011. Decoupling of standard implementation from certification: does quality of ISO 14001 implementation affect facilities' environmental performance? Business Ethics Quarterly 21 (1) 73-102.

Arimura, T.H., N. Darnall, and H. Katayama. 2010. Is ISO 14001 a gateway to more advanced voluntary action? The case of green supply chain management. Journal of Environmental Economics and Management 61: 170-182.

Arimura, T.H., N. Darnall, R. Ganguli, and H. Katayama. 2016. The effect of ISO 14001 on environmental performance: Resolving equivocal findings. Journal of Environmental Management 166: 556-566.

Arnold, M. 2015. The lack of strategic sustainability orientation in German water companies. Ecological Economics 117: 39-52.

Babin, R., and B. Nicholson. 2009. Corporate social and environmental responsibility in global IT outsourcing. MIS Quarterly Executive 8 (4): 123-132.

Baek, K. 2017. The Diffusion of Voluntary Environmental Programs: The Case of ISO 14001 in Korea, 1996-2011. Journal of Business Ethics 145 (2): 325-336.

Bansal, P., and T. Hunter. 2003. Strategic explanations for the early adoption of ISO 14001. Journal of Business Ethics 46: 289-299.

Bansal, P., and W. C. Bogner. 2002. Deciding on ISO 14001: economics, institutions, and context. Long Range Planning 35: 269-290.

Barla, P. 2007. ISO 14001 certification and environmental performance in Quebec's pulp and paper industry. Journal of Environmental Economics and Management 53: 291306.

Barney, J.B. 1991. Firm resources and sustained competitive advantage. Journal of Management 17 (1): 99-120. 
Boiral, O. 2007. Corporate greening through ISO 14001: a rational myth? Organization Science 18 (1): 127-146.

Boiral, O. 2011. Managing with ISO systems: lessons from practice. Long Range Planning 44: 197-220.

Boiral, O. 2012. ISO 9000 and Organizational Effectiveness: A Systematic Review. Quality Management Journal 19: 16-37.

Boiral, O., Guillaumie, L., Heras-Saizarbitoria, I. and Tayo Tene, C. V. 2017. Adoption and Outcomes of ISO 14001: A Systematic Review. International Journal of Management Reviews (0): 1-22

Boiral, O., J.-F., and Henri. 2012. Modelling the impact of ISO 14001 on environmental performance: A comparative approach. Journal of Environmental Management 99: 84-97.

Burns, T., and G. M. Stalker. 1961. The management of innovation. London: Tavistock.

Cagno, E., G. J. Micheli, and P. Trucco. 2012. Eco-efficiency for sustainable manufacturing: an extended environmental costing method. Production Planning and Control 23 (2-3): 134-144.

Carter, C. R., and P. L. Easton. 2011. Sustainable supply chain management: evolution and future directions. International Journal of Physical Distribution and Logistics Management 41 (1): 46-62.

Chiarini, A. 2014. Strategies for developing an environmentally sustainable supply chain: Differences between manufacturing and service sectors. Business Strategy and the Environment 23 (7): 493-504.

Chiarini, A. 2017. Setting Strategies outside a Typical Environmental Perspective Using ISO 14001 Certification. Business Strategy and the Environment 26 (6): 844-854. 
Child, J. 1997. Strategic choice in the analysis of action, structure, organizations and environment: retrospect and prospect. Organization studies 18 (1): 43-76.

Coase, R.H. 1937. The nature of the firm. Economica 4 (16): 386-405.

Corbett, C.J., and D. A. Kirsch 2001. International diffusion of ISO 14000 certification. Production and Operations Management 10 (3): 327-342.

Corbett, C.J., and D. A. Kirsch 2004. Response to "Revisiting ISO 14000 diffusion: a new "look" at the drivers of certification. Production and Operations Management 13 (3): $268-271$.

Darnall, N., and Y. Kim. 2012. Which types of environmental management systems are related to greater environmental improvements? Public Administration Review 72 (3): 351-365.

De Jong, P., A. Paulraj, and C. Blome. 2014. The financial impact of ISO 14001 certification: top-line, bottom-line, or both? Journal of Business Ethics 119 (1): 131149.

De Oliveira Matias, J. C., and D. A. Coelho, 2002. The integration of the standards systems of quality management, environmental management and occupational health and safety management. International Journal of Production Research 40 (15): 38573866.

Del Brío, J.Á., and B. Junquera. 2003. Influence of the perception of the external environmental pressures on obtaining the ISO 14001 standard in Spanish industrial companies. International Journal of Production Research 41 (2): 337-348.

Delmas, M. 2001. Stakeholders and competitive advantage: the case of ISO 14001. Production and Operations Management 10 (3): 343-358. 
Delmas, M., and I. Montiel. 2009. Greening the supply chain: when is customer pressure effective? Journal of Economics and Management Strategy 18 (1): 171-201.

Delmas, M.A., and M. J. Montes-Sancho. 2011. An institutional perspective on the diffusion of international management system standards: the case of the environmental management standard ISO 14001. Business Ethics Quarterly 21 (1): $103-132$.

Delmas, M.A., and M. W. Toffel. 2008. Organizational responses to environmental demands: opening the black box. Strategic Management Journal 29: 1027-1055.

DiMaggio, P., and W. W. Powell. 1983. The iron cage revisited: Collective rationality and institutional isomorphism in organizational fields. American Sociological Review 48 (2): 147-160.

Donaldson, L. 2001. The contingency theory of organizations. Thousand Oaks: Sage.

Donaldson, T., and L. E. Preston, 1995. The Stakeholder Theory of the Corporation: Concepts, Evidence, and Implications. Academy of Management Review 20 (1): 6591.

Duriau, V.J., R. K. Reger, and M. D. Pfarrer. 2007. A content analysis of the content analysis literature in organization studies: research themes, data sources, and methodological refinements. Organizational Research Methods 10 (1): 5-34.

Evans, J. R., Foster Jr., S. T., and Linderman, K. (2014). A content analysis of research in quality management and a proposed agenda for future research. Quality Management Journal 21(2): 17-44

European Commission 2014. Sustainable Development, available at: ttp://ec.europa.eu/ environment/eussd/escp_en.htm (accessed: 2015-4-10). 
Fahimnia, B., J. Sarkis, and H. Davarzani. 2015. Green supply chain management: A review and bibliometric analysis. International Journal of Production Economics 162: $101-114$.

Ferrón-Vílchez, V. 2016. Does symbolism benefit environmental and business performance in the adoption of ISO 14001? Journal of Environmental Management 183: 882894.

Freeman, R.E. 1984. Strategic management: A stakeholder approach. Boston: Pitman.

Fryxell, G.E., A. Szeto. 2002. The influence of motivations for seeking ISO 14001 certification: An empirical study of ISO 14001 certified facilities in Hong Kong. Journal of Environmental Management 64 (3): 223-238

González, P., J. Sarkis, and B. Adenso-Diaz. 2008. Environmental management system certification and its influence on corporate practices: Evidence from the automotive industry. International Journal of Operations and Production Management 28 (11): 1021-1041.

González-Benito, J., and O. González-Benito. 2005. An analysis of the relationship between environmental motivations and ISO14001 certification. British Journal of Management 16: 133-148.

González-Benito, J., and O. González-Benito. 2008. Operations management practices linked to the adoption of ISO 14001: an empirical analysis of Spanish manufacturers. International Journal of Production Economics 113: 60-73.

Gosling, J., and M. M. Naim. 2009. Engineer-to-order supply chain management: A literature review and research agenda. International Journal of Production Economics 122 (2): 741-754. 
Graafland, J., H. Smid. 2016. Environmental Impacts of SMEs and the Effects of Formal Management Tools: Evidence from EU's Largest Survey. Corporate Social Responsibility and Environmental Management 23 (5): 297-303.

Green, S.E. 2004. A rhetorical theory of diffusion. Academy of Management Review 29 (4): 653-669.

Gupta, S., R. Innes. 2014. Private politics and environmental management. Journal of Environmental Economics and Management 68 (2): 319-339.

Harvey, C., A. Kelly, H. Morris, and M. Rowlinson. 2010. Academic Journal Quality Guide Version 4, London: The Association of Business Schools.

He, W., R. Shen. 2017. ISO 14001 Certification and Corporate Technological Innovation: Evidence from Chinese Firms. Journal of Business Ethics 1-21 doi: 10.1007/s10551-017-3712-2.

He, W., W. Yang, and S.-J. Choi. 2016. The Interplay Between Private and Public Regulations: Evidence from ISO 14001 Adoption Among Chinese Firms. Journal of Business Ethics 1-21. doi: 10.1007/s10551-016-3280-x.

Hemerling, J., and D. Lee. 2007. Sourcing from China - Lessons from the leaders. The Boston Consulting Group.

Heras $\square$ Saizarbitoria, I., and O. Boiral. 2013. ISO 9001 and ISO 14001: towards a research agenda on management system standards. International Journal of Management Reviews 15 (1) 47-65.

Heras-Saizarbitoria, I., G. A. Landín, and J. F. Molina-Arzorín. 2011. Do drivers matter for the benefits of ISO 14001? International Journal of Operations and Production Management 31(2): 192-215. 
Hsu, C.-C., K. C. Tan, S. H. M. Zailani, and V. Jayaraman. 2013. Supply chain drivers that foster the development of green initiatives in an emerging economy. International Journal of Operations and Production Management 33 (6): 656-688.

Husted, B.W., I. Montiel, and P. Christmann. 2016. Effects of local legitimacy on certification decisions to global and national CSR standards by multinational subsidiaries and domestic firms. Journal of International Business Studies 47 (3): 382-397.

Iatridis, K., and E. Kesidou. 2018. What Drives Substantive Versus Symbolic Implementation of ISO 14001 in a Time of Economic Crisis? Insights from Greek Manufacturing Companies. Journal of Business Ethics, 148 (4): 859-877.

Inoue, E., T.H. Arimura, and M. Nakano. 2013. A new insight into environmental innovation: Does the maturity of environmental management systems matter? Ecological Economics 94: 156-163.

ISO 2013. The ISO Survey of Management System Standard Certifications - 2013. International Organization for Standardization, http://www.iso.org/iso/isosurvey executive-summary.pdf?v2013 (accessed: 2015-1-30).

ISO 2018. The ISO Survey of Management System Standard Certifications 2017. Available online at: https://isotc.iso.org/livelink/livelink? func=11\&objId=18808772\&objActi $\underline{\text { on=browse \&view Type }=1}$ (accessed: 2018-09-07).

Ivanova, A., J. Gray, and K. Sinha. 2014. Towards a unifying theory of management standard implementation: The case of ISO 9001/ISO 14001. International Journal of Operations and Production Management 34 (10): 1269-1306. 
Jacobs, B. W., V. R. Singhal, and R. Subramanian. 2010. An empirical investigation of environmental performance and the market value of the firm. Journal of Operations Management 28: 430-441.

Jiang, R. J., and P. Bansal. 2003. Seeing the need for ISO 14001. Journal of Management Studies 40 (4): 1047-1067.

Johanson, J., and F. Wiedersheim-Paul. 1975. The internationalization of the firm-four Swedish cases. Journal of Management Studies 12 (3): 305-323.

Johnsen, T. E. 2009. Supplier involvement in new product development and innovation: Taking stock and looking to the future. Journal of Purchasing and Supply Management 15 (3): 187-197.

Johnstone, N., and J. Labonne. 2008. Why do manufacturing facilities introduce environmental management systems? Improving and/or signaling performance. Ecological Economics 68: 719-730.

Kaplan, R. S., and D. P. Norton (1992). The Balance Scorecard - Measures that Drive Performance. Harvard Business Review 83 (7): 172-180.

King, A. A., and M. J. Lenox, 2001. Lean and green? An empirical examination of the relationship between lean production and environmental performance. Production and Operations Management 10 (3): 244-256.

King, A. A., M. J. Lenox, and A. Terlaak. 2005. The strategic use of decentralized institutions: exploring certification with the ISO 14001 management standard. Academy of Management Journal, 48 (6): 1091-1106.

Kitazawa, S., and J. Sarkis. 2000. The relationship between ISO 14001 and continuous source reduction programs. International Journal of Operations and Production Management 20 (2): 225-248. 
Klassen, R., and S. Vachon. 2003. Collaboration and evaluation in the supply chain: the impact on plant-level environmental investment. Production and Operations Management 12 (3): 336-352.

Kwon, D.-M., M.-S. Seo, and Y.-C. Seo. 2002. A study of compliance with environmental regulations of ISO 14001 certifed companies in Korea. Journal of Environmental Management 65: 347-353.

Lee, S.Y., and R. D. Klassen. 2008. Drivers and enablers that foster environmental management capabilities in small-and medium-sized suppliers in supply chains. Production and Operations Management 17 (6): 573-586.

Lee, V.-H., K.-B. Ooi, A.Y.-L. Chong, B. Lin. 2015. A structural analysis of greening the supplier, environmental performance and competitive advantage. Production Planning and Control 26 (2) 116-130.

Lightfoot, H., T. Baines, and P. Smart. 2013. The servitization of manufacturing: A systematic literature review of interdependent trends. International Journal of Operations and Production Management 33 (11/12): 1408-1434.

Lim, S., and A. Prakash. 2014. Voluntary Regulations and Innovation: The Case of ISO 14001. Public Administration Review 74 (2): 233-244.

Link, S., and E. Naveh. 2006. Standardization and discretion: does the environmental standard ISO 14001 lead to performance benefits? IEEE Transactions on Engineering Management 53 (4): 508-519.

Lo, K. Y., A. C. L. Yeung, and T. C. E. Cheng. 2012. The impact of environmental management system on financial performance in fashion and textiles industries. International Journal of Production Economics 135: 561-567. 
Marchet, G., M. Melacini, and S. Perotti. 2014. Environmental sustainability in logistics and freight transportation: A literature review and research agenda. Journal of Manufacturing Technology Management 25 (6): 775-811.

Matthews, L., D. Power, A. Touboulic, and L. Marques. 2016. Building bridges: toward alternative theory of sustainable supply chain management. Journal of Supply Chain Management 52 (1): 82-94.

McGuire, W. 2014. The effect of ISO 14001 on environmental regulatory compliance in China. Ecological Economics 105: 254-264.

McKinsey 2013. The business of sustainability. New York: Report McKinsey.

Melnyk, S. A., R. P. Sroufe, and R. L. Calantone. 2002. Assessing the effectiveness of US voluntary environmental programmes: an empirical study. International Journal of Production Research 40 (8): 1853-1878.

Melnyk, S. A., R. P. Sroufe, and R. L. Calantone. 2003a. Assessing the impact of environmental management systems on corporate and environmental performance. Journal of Operations Management 21 (2): 329-351.

Melnyk, S. A., R. P. Sroufe, and R. L. Calantone. 2003b. A model of site-specific antecedents of ISO 14001 certification. Production and Operations Management 12 (3): 369-385.

Miemczyk, J., T. E. Johnsen and M. Macquet. 2012. Sustainable purchasing and supply management: a structured literature review of definitions and measures at the dyad, chain and network levels. Supply Chain Management: An International Journal 17 (5): 478-496. 
Mijatovic, I. S. and D. Stokic, 2010. The influence of internal and external codes on CSR practice: the case of companies operating in Serbia. Journal of Business Ethics 94: $533-552$.

Miles, M. P., L. S. Munilla, and G. R. Russell. 1997. Marketing and environmental registration/certification, what industrial marketers should understand about ISO 14000. Industrial Marketing Management 26: 363-370.

Molina-Azorín, J. F., E. Claver-Cortés, M. D. López-Gamero, and J. J. Tarí, 2009. Green management and financial performance: a literature review. Management Decision 47 (7): 1080-1100.

Monczka, R. M., and R. J. Trent. 1992. Global sourcing: A development approach. International Journal of Purchasing and Materials Management 27 (2): 2-8.

Montabon, F., M. Pagell, and Z. Wu. 2016. Making sustainability sustainable. Journal of Supply Chain Management 52 (2): 11-27.

Montiel, I., and B. W. Husted. 2009. The adoption of voluntary environmental management programs in Mexico: first movers as institutional entrepreneurs. Journal of Business Ethics 88: 349-363.

Montiel, I., B. W. Husted, and P. Christmann. 2012. Using private management standard certification to reduce information asymmetries in corrupt environments. Strategic Management Journal 33: 1103-1113.

Müller, R., S. Pemsel, and J. Shao. 2014. Organizational enablers for governance and governmentality of projects: A literature review. International Journal of Project Management, 32 (8): 1309-1320. 
Murphy, J., and A. Gouldson. 2000. Environmental policy and industrial innovation: integrating environment and economy through ecological modernisation. Geoforum 31 (1): 33-44.

Muskin, J. B. 2000. Interorganizational Ethics: standards of behaviour. Journal of Business Ethics 24: 283-297.

Nakamura, M., T. Takahashi, and I. Vertinsky. 2001. Why Japanese Firms Choose to Certify: A Study of Managerial Responses to Environmental Issues. Journal of Environmental Economics and Management 42: 23-52.

Nakashima, K., T. Nose, and S. Kuriyama. 2006. A new approach to environmentalperformance evaluation. International Journal of Production Research 44 (18-19): 4137-4143.

Narayanan, V., L. J. Zane, and B. Kemmerer. 2011. The cognitive perspective in strategy: an integrative review. Journal of Management 37 (1): 305-351.

Neves, F.D.O., E.G. Salgado, and L.A. Beijo. 2017. Analysis of the Environmental Management System based on ISO 14001 on the American continent. Journal of Environmental Management 199: 251-262.

Nishitani, K. 2008. An empirical study of the initial adoption of ISO 14001 in Japanese manufacturing firms. Ecological Economics 68: 669-679.

Orsato, R. J. 2006. Competitive environmental strategies: when does it pay to be green? California Management Review 48 (2): 127-143

Pagell, M., and A. Shevchenko. 2014. "Why research in sustainable supply chain management should have no future." Journal of Supply Chain Management 50 (1): 44-55. 
Pallaro, E., N. Subramanian, M. D. Abdulrahman, and C. Liu. 2015. Sustainable production and consumption in the automotive sector: Integrated review framework and research directions. Sustainable Production and Consumption 4: 47-61. doi:10.1016/j.spc.2015.07.002.

Paulraj, A., and P. de Jong. 2011. The effect of ISO 14001 certification announcements on stock performance. International Journal of Operations and Production Management $31(7): 765-788$.

Prajogo, D., A. K. Y. Tang, and K. H. Lai. 2014. The diffusion of environmental management system and its effect on environmental management practices. International Journal of Operations and Production Management 34 (5): 565-585.

Rajagopal, S., and K. N. Bernard. 1993. Globalization of the procurement process, Marketing Intelligence and Planning 11 (7): 44-56.

Radziwill, N. M. (2013). A review of research in the quality management journal: Influential resources, key themes, and emerging trends. Quality Management Journal 20(1): 7-36

Reynolds, M. A., and K. Yuthas. 2008. Moral discourse and corporate social responsibility reporting. Journal of Business Ethics 78 (1-2): 47-64.

Rogers, E. M. 1995. Lessons for guidelines from the diffusion of innovations. The Joint Commission journal on quality improvement 21 (7): 324.

Rostow, W. W. 1960. The stages of growth: A non-communist manifesto. Cambridge: Cambridge University Press.

Rousseau, D. M., J. Manning, and D. Denyer. 2008. Evidence in Management and Organizational Science: Assembling the Field's Full Weight of Scientific Knowledge Through Syntheses. Advanced Institute of Management Research 067. 
Sarkis, J., Q. Zhuand, and K.H. Lai 2011. An organizational theoretic review of green supply chain management literature. International Journal of Production Economics 130 (1): 1-15.

Sartor, M., G. Orzes, C. Di Mauro, M. Ebrahimpour, and G. Nassimbeni. 2016. The SA8000 social certification standard: Literature review and theory-based research agenda. International Journal of Production Economics 175: 164-181.

Schmenner, R.W., and M. L. Swink. 1998. On theory in operations management. Journal of Operations Management 17 (1): 97-113.

Schoenherr, T. 2012. The role of environmental management in sustainable business development: a multi-country investigation. International Journal of Production Economics, 140: 116-128.

Schoenherr, T., and S. Talluri. 2013. Environmental sustainability initiatives: a comparative analysis of plant efficiencies in Europe and the U.S. IEEE Transactions on Engineering Management 60 (2): 353-365.

Selznick, P. 1957. Leadership in administration: A sociological interpretation. New York: Harper and Row.

Senge, P. 1990. The fifth discipline: The art and science of the learning organization. New York: Currency Doubleday.

Simpson, D., D. Power, and D. Samson. 2007. Greening the automotive supply chain: a relationship perspective. International Journal of Operations and Production Management 27 (1): 28-48.

Spence, M. 1973. Job market signaling. The quarterly journal of Economics 87 (3): 355374. 
Srivastava, S. K. 2007. Green supply-chain management: a state-of-the-art literature review. International journal of management reviews 9 (1): 53-80.

Su, H.-C., S. Dhanorkar, and K. Linderman. 2015. A competitive advantage from the implementation timing of ISO management standards. Journal of Operations Management 37: 31-44.

Sullivan, R. 2005. Code integration: alignment or conflict? Journal of Business Ethics 59: 9-25.

Tarí, J. J., J. F. Molina-Azorín, and I. Heras. 2012. Benefits of the ISO 9001 and ISO 14001 standards: A literature review. Journal of Industrial Engineering and Management 5 (2): 297-322.

Teixeira, A. A., C. J. C. Jabbour, and A. B. L. de Sousa Jabbour. 2012. Relationship between green management and environmental training in companies located in Brazil: A theoretical framework and case studies. International Journal of Production Economics 140 (1): 318-329.

Testa, F., F. Iraldo, M. Frey, and T. Daddi. 2012. What factors influence the uptake of GPP (green public procurement) practices? New evidence from an Italian survey. Ecological Economics 82: 88-96.

Testa, F., O. Boiral, and F. Iraldo. 2018. Internalization of Environmental Practices and Institutional Complexity: Can Stakeholders Pressures Encourage Greenwashing? Journal of Business Ethics, 147 (2), 287-307.

Thomé, A. M. T., L. F., Scavarda, and A. J. Scavarda. 2016. Conducting systematic literature review in operations management. Production Planning \& Control 27 (5): 408-420. 
Touboulic, A., and H. Walker. 2015. Theories in sustainable supply chain management: a structured literature review. International Journal of Physical Distribution and Logistics Management 45 (1/2): 16-42.

Tranfield, D., D. Denyer, and P. Smart. 2003. Towards a Methodology for Developing Evidence-Informed Management Knowledge by Means of Systematic Review. British Journal of Management 14: 207-222.

Trent, R. J., and R. M. Monczka. 2003. Understanding integrated global sourcing. International Journal of Physical Distribution and Logistics Management 33 (7): 607-629.

Tuppura, A., A.Toppinen, and K. Puumalainen. 2016. Forest Certification and ISO 14001: Current State and Motivation in Forest Companies. Business Strategy and the Environment 25 (5): 355-368.

Vastag, G. 2004. Revisiting ISO 14000 diffusion: a new "look" at the drivers of certification. Production and Operations Management 13 (3): 260-267.

Vastag, G., and S. A. Melnyk. 2002. Certifying environmental management systems by the ISO 14001 standards. International Journal of Production Research 40 (18): 47434763.

Viadiu, F. M., M. C. Fa, and I. Heras-Saizarbitoria. 2006. ISO 9000 and ISO 14000 standards: an international diffusion model. International Journal of Operations and Production Management 26 (2): 141-165.

Walker, H., S. Seuring, J. Sarkisand, R.D. Klassen. 2014. Sustainable operations management: recent trends and future directions. International Journal of Operations and Production Management 34 (5). DOI: 10.1108/IJOPM-12-2013-0557. 
Whiteman, G., B. Walker, and P. Perego 2013. Planetary boundaries: Ecological foundations for corporate sustainability. Journal of Management Studies 50 (2): 307336.

Wiengarten, F., P. Humphreys, G. Onofrei, B. Fynes. 2017. The adoption of multiple certification standards: perceived performance implications of quality, environmental and health \& safety certifications. Production Planning and Control 28 (2): 131-141.

Williamson, O. E. (1975). Markets and hierarchies: analysis and antitrust implications. New York: The Free Press.

Xu, X.D., S.X. Zeng, H.L. Zou, and J.J. Shi. 2016. The Impact of Corporate Environmental Violation on Shareholders' Wealth: A Perspective Taken from Media Coverage. Business Strategy and the Environment 25 (2): 73-91.

Zailani, S. H. M., T. K. Eltayeb, C. C. Hsu, and K. C. Tan. 2012. The impact of external institutional drivers and internal strategy on environmental performance. International Journal of Operations and Production Management 32 (6): 721-745.

Zhu, Q., J. Cordeiro, and J. Sarkis, 2012a. "nternational and domestic pressures and responses of Chinese firms to greening. Ecological Economics 83: 144-153.

Zhu, Q., Y. Tian, and J. Sarkis, 2012b. Diffusion of selected green supply chain management practices: an assessment of Chinese enterprises. Production Planning and Control 23 (10-11) 837-850.

Zutshi, A., and A. Sohal. 2004a. Environmental management system adoption by Australasian organisations: part 1: reasons, benefits and impediments. Technovation 24: 335-357. 
Zutshi, A., and A. Sohal. 2004b. A study of the environmental management system (EMS) adoption process within Australasian organisations - 2. Role of stakeholders. Technovation 24: 371-386.

Appendix A: Synthesis of the literature

[Insert Table A1 about here] 
Figure 1: Literature review framework

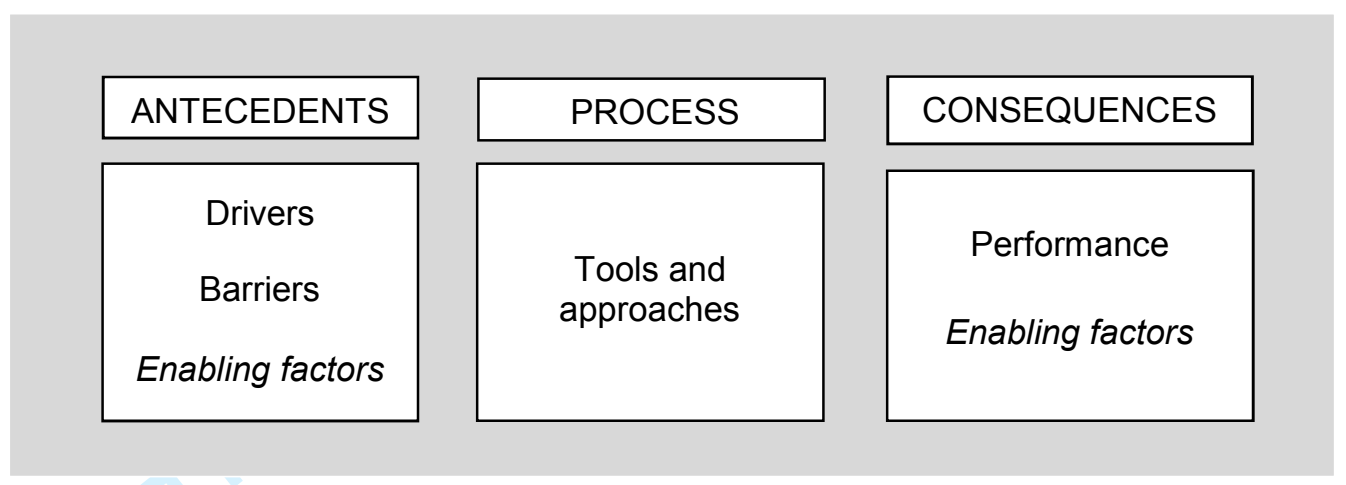




\section{Figure 2: Research Agenda}

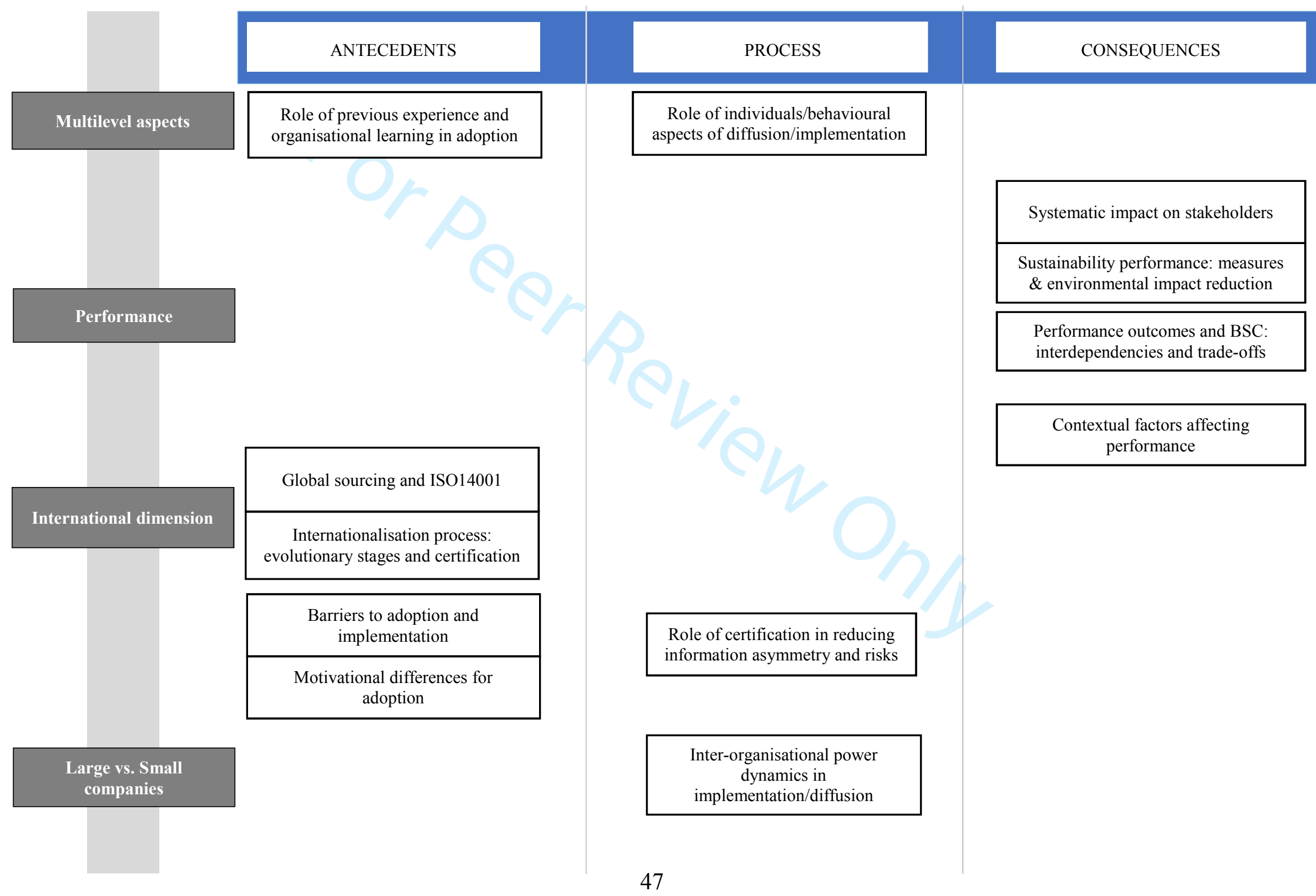

URL: https://mc.manuscriptcentral.com/qmj 
Table 1: Breakdown of ISO 14001 certificates by industry (adapted from ISO, 2018)

\section{Industry}

Agriculture, fishing and forestry

Mining and quarrying

Food products, beverage and tobacco

Textiles and textile products

Pulp, paper and paper products

Printing companies

Chemicals, chemical products and fibres

Rubber and plastic products

Non-metallic mineral products

Concrete, cement, lime, plaster etc.

Basic metal and fabricated metal products

Machinery and equipment

Electrical and optical equipment

Other transport equipment

Manufacturing not elsewhere classified

Recycling

Electricity supply

Construction

Wholesale and retail trade, repairs of motor vehicles/ motorcycles/personal/household goods

Transport, storage and communication

Financial intermediation, real estate, renting

Information technology

Engineering services

Other

\begin{tabular}{cc}
$\begin{array}{c}\text { N. of certificates } \\
\text { in 2017 }\end{array}$ & $\%$ \\
\hline 2396 & $0.87 \%$ \\
\hline 2429 & $0.88 \%$ \\
\hline 6402 & $2.32 \%$ \\
\hline 4299 & $1.56 \%$ \\
\hline 2894 & $1.05 \%$ \\
\hline 2871 & $1.04 \%$ \\
\hline 11734 & $4.25 \%$ \\
\hline 14091 & $5.11 \%$ \\
\hline 3410 & $1.24 \%$ \\
\hline 4433 & $1.61 \%$ \\
\hline 26136 & $9.48 \%$ \\
\hline 16202 & $5.88 \%$ \\
\hline 25642 & $9.30 \%$ \\
\hline 3696 & $1.34 \%$ \\
\hline 4173 & $1.51 \%$ \\
\hline 2788 & $1.01 \%$ \\
\hline 2017 & $0.73 \%$ \\
\hline 51384 & $18.63 \%$ \\
\hline 23848 & $8.65 \%$ \\
\hline 7585 & $2.75 \%$ \\
\hline 6063 & $2.20 \%$ \\
\hline 8620 & $3.13 \%$ \\
\hline 16213 & $5.88 \%$ \\
\hline 26450 & $9.59 \%$ \\
\hline & \\
\hline
\end{tabular}


Table 2: Breakdown of ISO 14001 certificates by country (adapted from ISO, 2018)

\begin{tabular}{|c|c|c|}
\hline Continent/country & $\begin{array}{l}\text { N. of cert. } \\
\text { in } 2017\end{array}$ & $\%$ \\
\hline Africa & 3083 & $0.85 \%$ \\
\hline South Africa & 1230 & $0.34 \%$ \\
\hline Egypt & 721 & $0.20 \%$ \\
\hline Tunisia & 216 & $0.06 \%$ \\
\hline Other countries & 916 & $0.25 \%$ \\
\hline North America & 8124 & $2.24 \%$ \\
\hline USA & 5251 & $1.45 \%$ \\
\hline Mexico & 1701 & $0.47 \%$ \\
\hline Canada & 1172 & $0.32 \%$ \\
\hline Central/South America & 10301 & $2.84 \%$ \\
\hline Colombia & 2954 & $0.81 \%$ \\
\hline Brazil & 2948 & $0.81 \%$ \\
\hline Argentina & 1458 & $0.40 \%$ \\
\hline Chile & 1419 & $0.39 \%$ \\
\hline Other countries & 1522 & $0.42 \%$ \\
\hline Europe & 112790 & $31.11 \%$ \\
\hline United Kingdom & 17559 & $4.84 \%$ \\
\hline Italy & 14571 & $4.02 \%$ \\
\hline Spain & 13053 & $3.60 \%$ \\
\hline Germany & 12176 & $3.36 \%$ \\
\hline Sweden & 6486 & $1.79 \%$ \\
\hline France & 6318 & $1.74 \%$ \\
\hline Other countries & 42627 & $11.76 \%$ \\
\hline East Asia and Pacific & 214621 & $59.19 \%$ \\
\hline China & 165665 & $45.69 \%$ \\
\hline Japan & 23901 & $6.59 \%$ \\
\hline South Korea & 5351 & $1.48 \%$ \\
\hline Australia & 3938 & $1.09 \%$ \\
\hline Thailand & 3405 & $0.94 \%$ \\
\hline Other countries & 12361 & $3.41 \%$ \\
\hline Central and South Asia & 8896 & $2.45 \%$ \\
\hline India & 7887 & $2.18 \%$ \\
\hline Pakistan & 350 & $0.10 \%$ \\
\hline Other countries & 659 & $0.18 \%$ \\
\hline Middle-East & 4795 & $1.32 \%$ \\
\hline United Arab Emirates & 1711 & $0.47 \%$ \\
\hline Israel & 883 & $0.24 \%$ \\
\hline Iran & 710 & $0.20 \%$ \\
\hline Other countries & 1491 & $0.41 \%$ \\
\hline
\end{tabular}


Table 3: Underpinning theories

\begin{tabular}{|c|c|c|c|}
\hline Theory & Key issues & $\begin{array}{c}\# \\
\text { papers }\end{array}$ & Adoption in ISO14001 research \\
\hline $\begin{array}{l}\text { Institutional and } \\
\text { Neo-Institutional } \\
\text { Theories } \\
\text { Selznick (1957) } \\
\text { and DiMaggio and } \\
\text { Powell (1983) }\end{array}$ & $\begin{array}{l}\text { Companies receive pressure from the } \\
\text { environment in which they operate and tend to } \\
\text { conform to these in order to survive } \\
\text { (Institutional Theory) } \\
\text { Among these pressures, there are also social } \\
\text { ones. They can be classified into three main } \\
\text { categories: coercive pressures, normative } \\
\text { pressures, mimetic pressures (Neo-Institutional } \\
\text { Theory) }\end{array}$ & 16 & $\begin{array}{l}\text { Adoption and diffusion of ISO } 14001 \text { is primarily related to coercive, } \\
\text { normative or mimetic pressures (Delmas and Montes-Sancho 2011; } \\
\text { Heras-Saizarbitoria, Landín, and Molina-Arzorín 2011; Hsu et al. } \\
\text { 2013; Zailani et al. 2012; Jiang and Bansal 2003; Zhu et al. 2012a; } \\
\text { King, Lenox, and Terlaak 2005; Husted et al. 2016; Baek 2017 ) } \\
\text { Firms that are subjected to different external pressures adopt distinct } \\
\text { sets of management practices (Delmas and Toffel 2008; González, } \\
\text { Sarkis, and Adenso-Diaz 2008; Schoenherr and Talluri 2013; Testa } \\
\text { et al. 2015; He, Yang, and Choi 2016) } \\
\text { The external pressure could force firm to adopt ISO 14001 just for its } \\
\text { signalling role (Aravind and Christmann 2011; Boiral 2007; Montiel, } \\
\text { Husted, Christmann 2012) }\end{array}$ \\
\hline $\begin{array}{l}\text { Resource Based } \\
\text { View } \\
\text { Barney (1991) }\end{array}$ & $\begin{array}{l}\text { The competitiveness of a company derives } \\
\text { from the ability to develop, integrate and } \\
\text { coordinate different resources and capabilities }\end{array}$ & 7 & $\begin{array}{l}\text { ISO 14001 can be seen as an intangible resource (Delmas 2001; } \\
\text { Orsato 2006; Schoenherr 2012; Schoenherr and Talluri 2013; Baek } \\
\text { 2017) } \\
\text { Larger firms tend to have greater implementation of environmental } \\
\text { practices due to their access to additional resources (González, } \\
\text { Sarkis, and Adenso-Diaz 2008) } \\
\text { ISO } 14001 \text { affects corporate technological innovation through the } \\
\text { mediating role of the resources (He and Shen 2017) }\end{array}$ \\
\hline $\begin{array}{l}\text { Stakeholder } \\
\quad \text { Theory } \\
\text { Freeman (1984) }\end{array}$ & $\begin{array}{l}\text { The company's behaviour is affected by the } \\
\text { interests of the major stakeholder groups }\end{array}$ & 3 & $\begin{array}{l}\text { Stakeholders put pressure on supply chains for the adoption of } \\
\text { environmentally friendly practices (González, Sarkis, and Adenso- } \\
\text { Diaz 2008; Zailani et al. 2012; Testa et al. 2018) }\end{array}$ \\
\hline
\end{tabular}


Table 3 (continued)

\begin{tabular}{|c|c|c|c|}
\hline Theory & Key issues & $\begin{array}{c}\# \\
\text { papers }\end{array}$ & Adoption in ISO14001 research \\
\hline $\begin{array}{l}\text { Signalling } \\
\text { Theory } \\
\text { Spence (1973) }\end{array}$ & $\begin{array}{l}\text { Individuals develop communication signals in } \\
\text { order to convey information to other individuals } \\
\text { and influence their behaviour. }\end{array}$ & 3 & $\begin{array}{l}\text { ISO } 14001 \text { could reduce information asymmetries in supplier- } \\
\text { customer relationships (Delmas and Montiel 2009) } \\
\text { Firms could adopt ISO } 14001 \text { as a signal to the external } \\
\text { environment ( Montiel, Husted, Christmann 2012; Xu et al. } \\
\text { 2016) }\end{array}$ \\
\hline $\begin{array}{l}\text { Transaction Cost } \\
\text { Economics } \\
\text { Coase (1937), } \\
\text { Williamson } \\
\text { (1975) }\end{array}$ & $\begin{array}{l}\text { The company's goal is to minimize transaction } \\
\text { costs, which depend on the characteristics of the } \\
\text { transaction (asset specificity, uncertainty, and } \\
\text { frequency) }\end{array}$ & 2 & $\begin{array}{l}\text { Suppliers involved in more asset-specialized transactions are } \\
\text { more likely to adopt the ISO } 14001 \text { certification (Delmas and } \\
\text { Montiel 2009) } \\
\text { Firms located in jurisdictions characterized by high levels of } \\
\text { policy-specific corruptions are more likely to adopt the } \\
\text { certification (since it acts as a signal of desirable corporate } \\
\text { conduct) (Montiel, Husted, Christmann 2012) }\end{array}$ \\
\hline $\begin{array}{l}\text { Rhetorical } \\
\text { Theory of } \\
\text { Diffusion } \\
\text { Green (2004) }\end{array}$ & $\begin{array}{l}\text { The spread of management practices depends on } \\
\text { persuasiveness of discursive justifications used to } \\
\text { rationalize them }\end{array}$ & 1 & $\begin{array}{l}\text { The diffusion of ISO } 14001 \text { could be explained also by the } \\
\text { rational rhetoric supporting this practice (Boiral 2007) }\end{array}$ \\
\hline $\begin{array}{l}\text { Diffusion of } \\
\text { Innovations } \\
\text { Theory } \\
\text { Rogers (1995) }\end{array}$ & $\begin{array}{l}\text { It explains how, why, and at what rate new ideas } \\
\text { and technology spread. Innovation itself, } \\
\text { communication channels, time, the social system } \\
\text { are the four elements considered for the diffusion } \\
\text { analysis. }\end{array}$ & 1 & $\begin{array}{l}\text { The diffusion of environmental practices, such as ISO 14001, } \\
\text { among the organizations follows some pre-defined stages (Zhu } \\
\text { et al. 2012b) }\end{array}$ \\
\hline $\begin{array}{l}\text { Strategic Choice } \\
\text { Theory } \\
\text { Child (1997) } \\
\end{array}$ & $\begin{array}{l}\text { The strategy adopted by a company is oriented by } \\
\text { performance targets. The company adopt the } \\
\text { strategy if its benefits outweigh the costs. }\end{array}$ & 1 & $\begin{array}{l}\text { Environmental practices positively affects environmental } \\
\text { performance (Zailani et al. 2012) }\end{array}$ \\
\hline
\end{tabular}


Table 3(continued)

\begin{tabular}{|c|c|c|c|}
\hline Theory & Key issues & $\begin{array}{c}\# \\
\text { papers }\end{array}$ & Adoption in ISO14001 research \\
\hline $\begin{array}{l}\text { Organizational } \\
\text { Climate Theory } \\
\text { Senge (1990) }\end{array}$ & $\begin{array}{l}\text { The implementation of certain management } \\
\text { practices is in line with the climatic } \\
\text { characteristics of the context in which they are } \\
\text { developed }\end{array}$ & 1 & $\begin{array}{l}\text { Environmental management system diffusion will create } \\
\text { "green" climate across different organisational functions } \\
\text { which will support the implementation of associated } \\
\text { management practices (Prajogo, Tang, and Lai 2014) }\end{array}$ \\
\hline $\begin{array}{l}\text { Theory of } \\
\text { Performance } \\
\text { Frontiers } \\
\text { Schmenner and } \\
\text { Swink (1998) }\end{array}$ & $\begin{array}{l}\text { The performance of an enterprise are subject to } \\
\text { an upper limit, given a particular set of } \\
\text { operational choices }\end{array}$ & 1 & $\begin{array}{l}\text { The effects of the ISO } 14001 \text { certification on firm performance } \\
\text { are lower for plants located in industrialized countries than for } \\
\text { those located in developing countries (Schoenherr 2012) }\end{array}$ \\
\hline $\begin{array}{c}\text { Competitive } \\
\text { Dynamics Theory } \\
\text { Young (1996) }\end{array}$ & $\begin{array}{l}\text { The potential performance benefits depend on } \\
\text { implementing practices earlier than others }\end{array}$ & 1 & $\begin{array}{l}\text { The timing of implementation of ISO } 14001 \text { has strategic } \\
\text { benefits (Su, Dhanorkar, and Linderman 2015) }\end{array}$ \\
\hline
\end{tabular}


Table 4: Drivers (number of papers is reported within square brackets)

5

6

7

8

9

\section{Green incentives [7]}

(Hsu et al. 2012; Hsu et al. 2013; HerasSaizarbitoria, Landín, and Molina-Arzorín 2011; Melnyk, Sroufe, and Calantone 2002; Alberti et al. 2000; Zutshi and Sohal 2004b; Neves, Salgado, and Beijo 2017)

\begin{tabular}{|c|c|c|c|}
\hline & ECONOMIC & HYBRID & ENVIRONMENTAL \\
\hline$\frac{Z}{2}$ & $\begin{array}{l}\text { Improve a company's image [20] } \\
\text { (González-Benito and González-Benito } \\
\text { 2008; King, Lenox, and Terlaak 2005; } \\
\text { González-Benito and González-Benito 2005; } \\
\text { Orsato 2006; Heras-Saizarbitoria, Landín, } \\
\text { and Molina-Arzorín 2011; Viadiu et al. } \\
\text { 2006; Vastag and Melnyk 2002; Alberti et } \\
\text { al. 2000; Jiang and Bansal 2003; Bansal and } \\
\text { Bogner 2002; Vastag 2004; Corbett and } \\
\text { Kirsch 2001; Zhu et al. 2012b; Zutshi and } \\
\text { Sohal 2004a; Zutshi and Sohal 2004b; } \\
\text { Chiarini 2017; Baek 2017; Tuppura et al. } \\
\text { 2016; Gupta and Innes 2014; Fryxell and } \\
\text { Szeto 2002) } \\
\text { Increase efficiency [12] } \\
\text { (González-Benito and González-Benito } \\
\text { 2005; Orsato 2006; Heras-Saizarbitoria, } \\
\text { Landín, and Molina-Arzorín 2011; Vastag } \\
\text { and Melnyk 2003a; Alberti et al. 2000; Jiang } \\
\text { and Bansal 2003; Melnyk, Sroufe, and } \\
\text { Calantone 2003b; Corbett and Kirsch 2001; } \\
\text { Zutshi and Sohal 2004b; Johnstone and } \\
\text { Labonne 2008; Iatridis and Kesidou 2018; } \\
\text { Tuppura et al. 2016) }\end{array}$ & $\begin{array}{l}\text { Reduce resource consumption [4] } \\
\text { (Lo, Yeung, and Cheng 2012; Alberti et al. 2000; Reynolds and } \\
\text { Yuthas 2008) } \\
\text { Reduce packaging and raw materials usage [1] } \\
\text { (González-Benito and González-Benito 2005) } \\
\text { Focus on foreign market [12] } \\
\text { (Bansal and Bogner 2002; Bansal and Hunter 2003; Corbett and } \\
\text { Kirsch 2001, 2004; Delmand and Montiel 2009; King, Lenox, } \\
\text { and Terlaak 2005; Montiel and Husted 2009; Nakamura, } \\
\text { Takahashi, and Vertinsky 2001; Nishitani 2008; Vastag 2004; } \\
\text { Iatridis and Kesidou 2018; Neves, Salgado, and Beijo 2017) } \\
\text { Improve Customer satisfaction [1] } \\
\text { (Tuppura et al. 2016) } \\
\text { Improve quality of processes and products [2] } \\
\text { (Tuppura et al. 2016; Kwon, Seo, and Seo 2002) }\end{array}$ & $\begin{array}{l}\text { Reduce toxics release [4] } \\
\text { (Alberti et al. 2000; Miles et al. 1997; } \\
\text { Reynolds and Yuthas 2008; Neves, } \\
\text { Salgado, and Beijo 2017) } \\
\text { Environmental sensitivity [8] } \\
\text { (González-Benito and González-Benito } \\
\text { 2008; González-Benito and González- } \\
\text { Benito 2005; Hsu et al. 2013, Heras- } \\
\text { Saizarbitoria, Landín, and Molina- } \\
\text { Arzorín 2011; Boiral 2007; Melnyk et } \\
\text { al. 2003b; Corbett and Kirsch 2001; } \\
\text { Zhu et al. 2012b) }\end{array}$ \\
\hline$\frac{\sum_{2}}{x}$ & $\begin{array}{l}\text { Green incentives [7] } \\
\text { (Hsu et al. 2012; Hsu et al. 2013; Heras- } \\
\text { Saizarbitoria, Landín, and Molina-Arzorín } \\
\text { 2011; Melnyk, Sroufe, and Calantone 2002; } \\
\text { Alberti et al. 2000; Zutshi and Sohal 2004b; } \\
\text { Neves, Salgado, and Beijo 2017) }\end{array}$ & $\begin{array}{l}\text { Reduce information asymmetries between } \\
\text { suppliers and buyers [4] } \\
\text { (King, Lenox, and Terlaak 2005; Jiang and Bansal 2003; } \\
\text { Montiel, Husted, Christmann 2012; Johnstone and Labonne } \\
\text { 2008) } \\
\text { Pressures by customers [24] } \\
\text { (Lo et al. 2012; King, Lenox, and Terlaak 2005; Orsato 2006; } \\
\text { Hsu et al. 2013; Del Brio and Junquera 2003; Alberti et al. 2000; } \\
\text { Miles, Munilla, and Russell 1997; Delmas and Montiel 2009; } \\
\text { Jiang and Bansal 2003; Bansal and Bogner 2002; Melnyk, } \\
\text { Sroufe, and Calantone 2003b; Corbett and Kirsh 2001; Zhu et } \\
\text { al. 2012; Delmas and Toffel 2008; Zutshi and Sohal 2004a; } \\
\text { McGuire 2014; González, Sarkis, and Adenso-Diaz 2008; } \\
\text { Vastag and Melnyk 2002; Viadiu et al. 2006; Montiel, Husted, } \\
\text { Christmann 2012; Delmas and Montes-Sancho 2011; Zhu et al. } \\
\text { 2002b; Teixeira 2012; Iatridis and Kesidou 2018) } \\
\\
\text { Pressures by suppliers [10] } \\
\text { (Viadiu 2006; Jiang and Bansal 2003; Bansal and Bogner 2002; } \\
\text { Zhu 2012b; Montiel 2012; Delmas and Toffel 2008; Zutshi and } \\
\text { Sohal 2004a; Delmas and Montes-Sancho 2011; Zhu et al. } \\
\text { 2012a; Teixeira, 2012) } \\
\text { Pressure by investor [6] } \\
\text { (Jiang and Bansal 2003; Miles, Munilla, and Russell 1997; } \\
\text { Delmas and Toffel 2008; Delmas and Montes-Sancho 2011; } \\
\text { Teixeira, 2012; Tuppura et al. 2016) } \\
\text { Competitors imitation [7] } \\
\text { (Hsu et al. 2013; Bansal and Bogner 2002; Zhu et al. 2012b; } \\
\text { Delmas and Toffel 2008; Husted et al. 2016; Tuppura et al. } \\
\text { 2016; Kwon, Seo, and Seo 2002) }\end{array}$ & $\begin{array}{l}\text { Environmental legal } \\
\text { requirements [17] } \\
\text { (King, Lenox, and Terlaak 2005; } \\
\text { Delmas and Montes-Sancho 2011; } \\
\text { Heras-Saizarbitoria, Landín, and } \\
\text { Molina-Arzorín 2011; Hsu et al. 2012; } \\
\text { Hsu et al. 2013; Del Brio and Junquera } \\
\text { 2003; Alberti et al. 2000; Bansal and } \\
\text { Bogner 2002; Delmas and Toffel 2008; } \\
\text { Zutshi and Sohal 2004a; Zutshi and } \\
\text { Sohal 2004b; Baek 2017; Iatridis and } \\
\text { Kesidou 2018; Neves et al. 2017; Gupta } \\
\text { and Innes 2014; Fryxell and Szeto } \\
\text { 2002; Kwon, Seo, and Seo 2002) }\end{array}$ \\
\hline
\end{tabular}


Table 5: Barriers

\begin{tabular}{|c|c|c|c|c|c|c|c|c|c|c|c|c|c|}
\hline & \multicolumn{2}{|c|}{ ADOPTION } & \multicolumn{7}{|c|}{ ONGOING MANAGEMENT } & \multicolumn{4}{|c|}{ BOTH } \\
\hline & 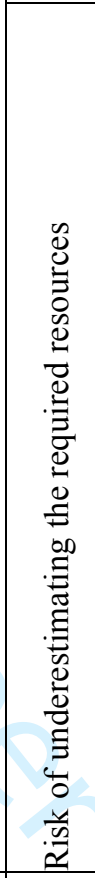 & 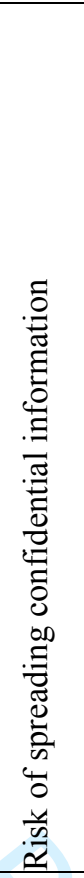 & 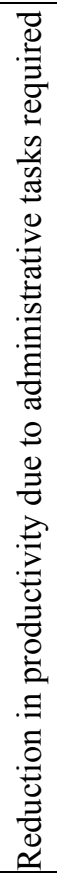 & 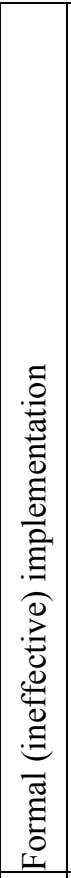 & 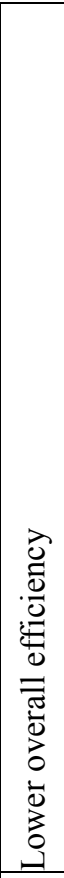 & 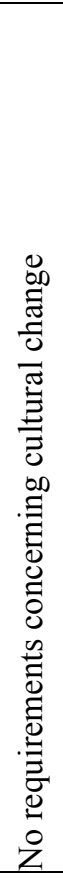 & 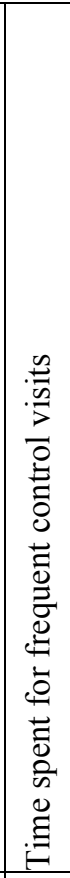 & 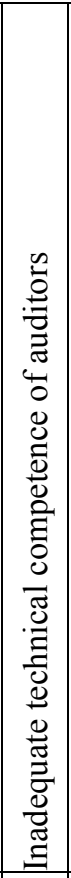 & 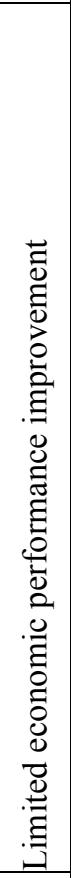 & 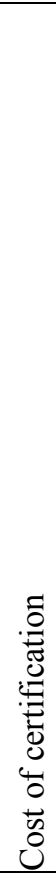 & 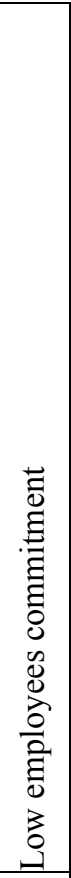 & 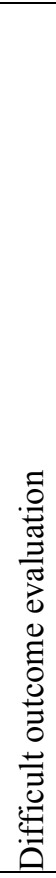 & 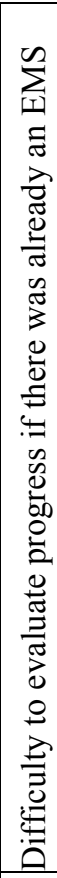 \\
\hline Alberti et al. 2000 & 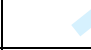 & 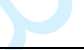 & & & & & & & & $\mathrm{x}$ & & & \\
\hline Bansal and Bogner 2002 & & 8 & $\mathrm{x}$ & & & & & $\mathrm{x}$ & & $\mathrm{x}$ & & $\mathrm{x}$ & $\mathrm{x}$ \\
\hline Boiral 2007 & & 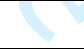 & 8 & $\mathrm{x}$ & & & $\mathrm{x}$ & & & & $\mathrm{x}$ & & $\mathrm{x}$ \\
\hline Boiral 2011 & $\mathrm{X}$ & $\mathrm{x}$ & $\mathrm{x}$ & $\mathrm{x}$ & & & & & & $\mathrm{x}$ & & & \\
\hline Chiarini 2017 & & & & 0 & & & & & $\mathrm{x}$ & & & & \\
\hline Del Brìo and Junquera 2003 & & & & $\mathrm{x}$ & $Q$ & & & & & & & & \\
\hline Delmas 2001 & & $\mathrm{x}$ & & . & 8 & 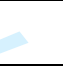 & & & & & & $\mathrm{x}$ & \\
\hline Ferrón-Vílchez 2016 & & & & $\mathrm{x}$ & & & 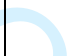 & & & & & & \\
\hline Iatridis and Kesidou 2018 & & & & $\mathrm{x}$ & & & 8 & & & & & & \\
\hline Jacobs, Singhal, and Subramanian 2010 & & & & & $\mathrm{x}$ & & + & 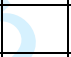 & & & & & \\
\hline Jiang and Bansal 2003 & & & & $\mathrm{x}$ & & & 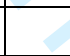 & & & & & & \\
\hline Kitazawa and Sarkis 2000 & & & & & & $\mathrm{x}$ & & & & & & & \\
\hline Melnyk, Sroufe, and Calantone 2003b & & & & & & & & & $\mathrm{x}$ & & & & \\
\hline Montiel, Husted, Christmann 2012 & & & & $\mathrm{x}$ & & & & & & & & & \\
\hline Orsato 2006 & & & & & & & & & & $\mathrm{x}$ & & & \\
\hline Schoenherr and Talluri 2013 & & & & & $\mathrm{x}$ & & & & & $\mathrm{x}$ & & & \\
\hline Sullivan 2005 & & & & & & & & & & & & $\mathrm{x}$ & \\
\hline Testa et al. 2018 & & & & $\mathrm{x}$ & & & & & & & & & \\
\hline Vastag and Melnyk 2002 & & & & & & & & & & & & $\mathrm{x}$ & \\
\hline Zhu et al. $2012 \mathrm{~b}$ & & & & & & & & & & $\mathrm{x}$ & & & \\
\hline Zutshi and Sohal 2004a & & $\mathrm{x}$ & $\mathrm{x}$ & & $\mathrm{x}$ & & & & & $\mathrm{x}$ & & & \\
\hline Zutshi and Sohal 2004b & $\mathrm{X}$ & $\mathrm{x}$ & & & & & & & & $\mathrm{x}$ & $\mathrm{x}$ & & \\
\hline TOTAL & 2 & 4 & 3 & 8 & 3 & 1 & 1 & 1 & 2 & 8 & 2 & 4 & 2 \\
\hline
\end{tabular}


Table 6: Enabling factors (N: Negative; P: Positive; X: No Effect; M: Mixed)

\begin{tabular}{|c|c|c|c|c|c|c|c|c|c|c|c|c|c|c|c|c|c|c|c|}
\hline & \multicolumn{14}{|c|}{ FIRM-SPECIFIC } & \multicolumn{5}{|c|}{ CONTEXTUAL } \\
\hline & 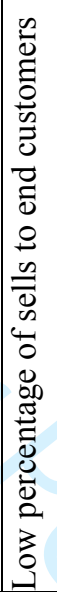 & 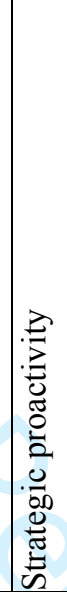 & 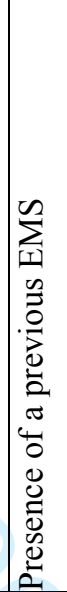 & 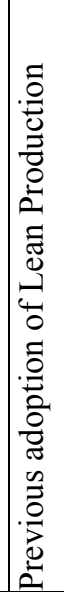 & 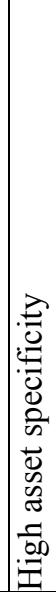 & 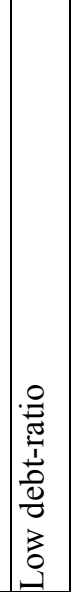 & 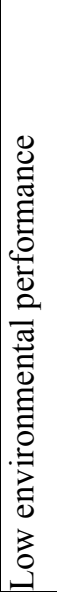 & 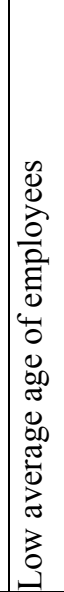 & 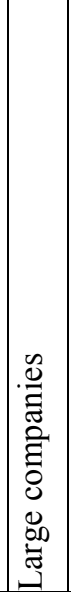 & 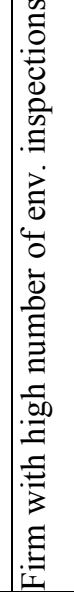 & 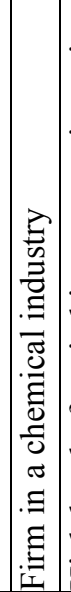 & 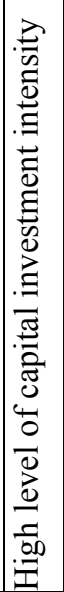 & 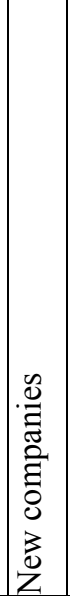 & 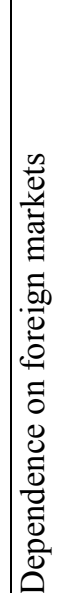 & 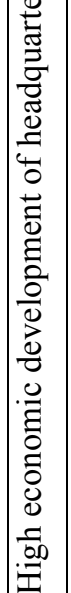 & 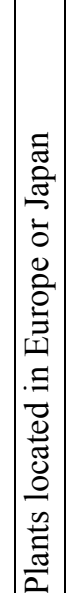 & 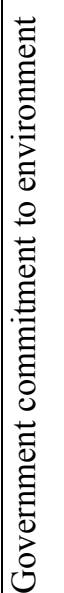 & 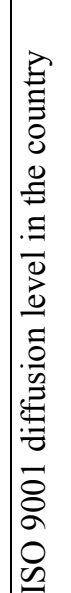 & 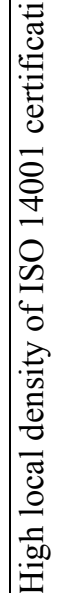 \\
\hline Alberti et al. 2000 & & $\mathrm{P}$ & & & & & & & $\mathrm{P}$ & & & & & & & & & & \\
\hline Arnold 2015 & & & & 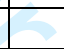 & & & & & & & & & & & & & & $\mathrm{P}$ & \\
\hline Baek 2017 & $\mathrm{~N}$ & & & & 8 & $\mathrm{~N}$ & & & $\mathrm{P}$ & & $\mathrm{P}$ & $\mathrm{X}$ & $\mathrm{M}$ & $\mathrm{P}$ & & & & $\mathrm{P}$ & \\
\hline Bansal and Bogner 2002 & & & & 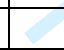 & 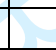 & & & & & & & & & & & & & & \\
\hline Bansal and Hunter 2003 & & & $\mathrm{P}$ & & & 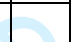 & & & & & & & & & & & & & \\
\hline Corbett and Kirsch 2001 & & $\mathrm{P}$ & & & $\bar{c}$ & O & & & & & & & & & $\mathrm{X}$ & & & $\mathrm{P}$ & \\
\hline Corbett and Kirsch 2004 & & & & & & & & & & & & & & & & & $\mathrm{P}$ & & \\
\hline Del Brìo and Junquera 2003 & & $\mathrm{P}$ & & & & & & & & & & & & & & & & & \\
\hline Delmas and Montes-Sancho 2011 & & & & & & & & & & & & & & & & & $\mathrm{P}$ & $P$ & \\
\hline Delmas and Montiel 2009 & & & $\mathrm{P}$ & & $\mathrm{P}$ & & 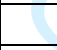 & 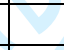 & 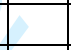 & & & & & & & $\mathrm{P}$ & & & \\
\hline Delmas and Toffel 2008 & & & & & & & & & $\mathrm{P}$ & & & & & & & & & & \\
\hline $\begin{array}{l}\text { González-Benito and González-Benito } \\
2005\end{array}$ & & $\mathrm{P}$ & & & & & & & $\mathrm{P}$ & & & & & & & & & & \\
\hline $\begin{array}{l}\text { González-Benito and González-Benito } \\
2008\end{array}$ & & $\mathrm{P}$ & & & & & & & & & & & & & & & & & \\
\hline Graafland and Smid 2016 & & & & & & & & & $\mathrm{P}$ & & P & 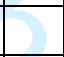 & & & & & & & \\
\hline Gupta and Innes 2014 & & & & & & & $\mathrm{P}$ & & $\mathrm{P}$ & $\mathrm{P}$ & & & & & & & & & \\
\hline He, Yang, and Choi 2016 & & & & & & & & & & & & & & & & & & $\mathrm{P}$ & \\
\hline $\begin{array}{l}\text { Heras-Saizarbitoria, Landín, and } \\
\text { Molina-Arzorín } 2011\end{array}$ & & $\mathrm{P}$ & & & & & & & & & & & & & & & & $\mathrm{X}$ & \\
\hline Husted, Montiel, and Christmann 2016 & & & & & & & & & & & & & & & & & & & $\mathrm{P}$ \\
\hline $\begin{array}{l}\text { Jacobs, Singhal, and Subramanian } \\
2010\end{array}$ & & $\mathrm{P}$ & & & & & & & & & & & & & & $\mathrm{P}$ & & & \\
\hline Jiang and Bansal 2003 & & & $\mathrm{P}$ & & & & & & $\mathrm{P}$ & & & & & & & & & & \\
\hline King and Lenox 2001 & & & $\mathrm{P}$ & $\mathrm{X}$ & & & & & & & & & & & & & & & \\
\hline King, Lenox, and Terlaak 2005 & & & $\mathrm{P}$ & & & & $\mathrm{P}$ & & & & & & & & & & & & \\
\hline Klassen and Vachon 2003 & & & & & & & & & $\mathrm{P}$ & & & & & & & & & & \\
\hline Melnyk, Sroufe, and Calantone 2003b & $\mathrm{P}$ & $\mathrm{P}$ & $\mathrm{M}$ & & & & & & & & & & & & & & & $\mathrm{N}$ & \\
\hline Miles, Munilla, and Russell 1997 & & & & & & & & & $\mathrm{P}$ & & & & & & & & & & \\
\hline
\end{tabular}


Table 6 (continued)

\begin{tabular}{|c|c|c|c|c|c|c|c|c|c|c|c|c|c|c|c|c|c|c|c|}
\hline & \multicolumn{14}{|c|}{ FIRM-SPECIFIC } & \multicolumn{5}{|c|}{ CONTEXTUAL } \\
\hline & 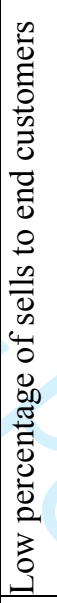 & 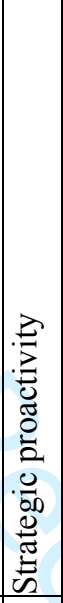 & 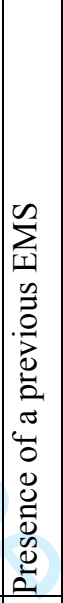 & 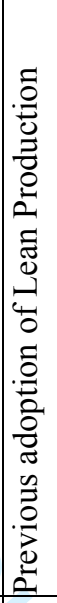 & 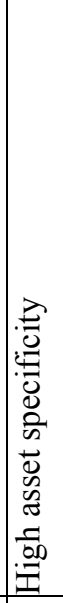 & 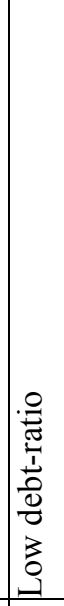 & 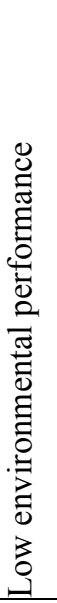 & 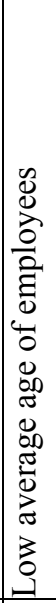 & 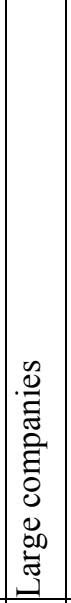 & 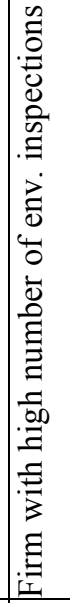 & 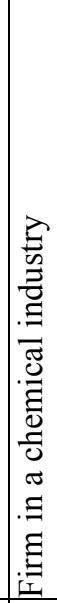 & 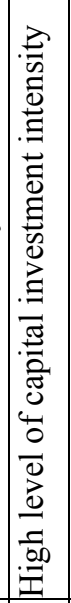 & 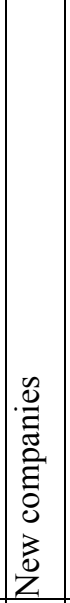 & 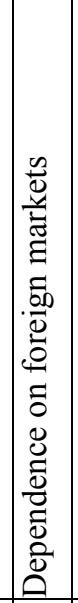 & 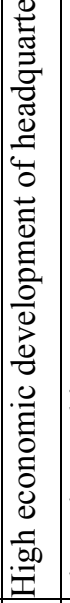 & 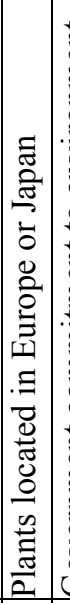 & 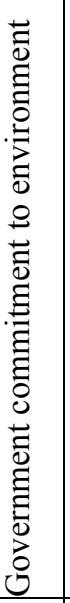 & 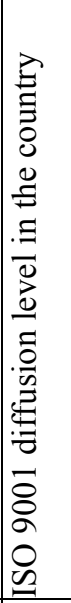 & 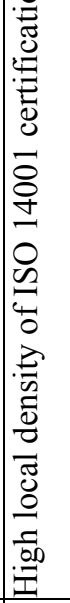 \\
\hline Montiel and Husted 2009 & & & & 8 & & & & & $\mathrm{P}$ & & & & & & & & & & \\
\hline Montiel, Husted, Christmann 2012 & & & & & 2 & & & & & & & & & & & & & & \\
\hline $\begin{array}{l}\text { Nakamura, Takahashi, and Vertinsky } \\
2001\end{array}$ & & & & 8 & 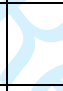 & $\mathrm{P}$ & & $\mathrm{P}$ & $\mathrm{P}$ & & & & & & & & & & \\
\hline Neves, Salgado, and Beijo 2017 & & & & & 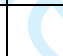 & V & $\mathrm{P}$ & & & & & & & $P$ & & & & $\mathrm{P}$ & \\
\hline Nishitani 2008 & & & & & & $\mathrm{P}$ & $C$ & 0 & $\mathrm{P}$ & & & & & & & & & & \\
\hline Schoenherr 2012 & & & & & & & & & & & & & & & $\mathrm{~N}$ & & & & \\
\hline Schoenherr and Talluri 2013 & & & & & & & & & & & & & & & & $\mathrm{P}$ & & & \\
\hline Teixeira 2012 & & $\mathrm{P}$ & & & & & & + & 1 & & & & & & & & & & \\
\hline Vastag 2004 & & & & & & & & & 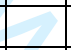 & & & & & & $\mathrm{P}$ & & $\mathrm{P}$ & $\mathrm{P}$ & \\
\hline Vastag and Melnyk 2002 & & & & & & & & & 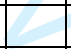 & 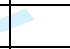 & & & & & & $\mathrm{P}$ & & & \\
\hline Viadiu et al.2006 & & & $\mathrm{P}$ & & & & & & & 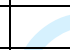 & 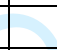 & & & & & $\mathrm{P}$ & & & \\
\hline Zhu et al. 2012b & & & & & & & & & & & & & & & & & $\mathrm{P}$ & & \\
\hline Zutshi and Sohal 2004b & & & $\mathrm{P}$ & & & & & & & 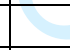 & P & & & & & & & & \\
\hline TOTAL & $\begin{array}{l}\mathbf{1 P} \\
1 \mathbf{N}\end{array}$ & 9P & $\begin{array}{l}7 P \\
1 M\end{array}$ & $1 X$ & 1P & $\begin{array}{l}2 \mathrm{P} \\
1 \mathrm{~N}\end{array}$ & $3 \mathbf{P}$ & 1P & $12 P$ & $1 P$ & $1 \mathrm{P}$ & $1 \mathrm{X}$ & $1 \mathrm{M}$ & $2 P$ & \begin{tabular}{l|}
$1 \mathrm{~N}$ \\
$1 \mathrm{P}$ \\
$1 \mathrm{X}$
\end{tabular} & $5 \mathbf{P}$ & $4 \mathbf{P}$ & \begin{tabular}{|l|}
$\mathbf{7 P}$ \\
$1 \mathrm{~N}$ \\
\end{tabular} & $1 \mathbf{P}$ \\
\hline
\end{tabular}


Table 7: Tools/methods

\begin{tabular}{|c|c|c|c|c|c|c|c|c|c|c|c|c|}
\hline & 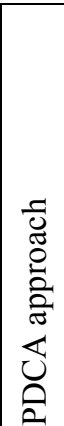 & 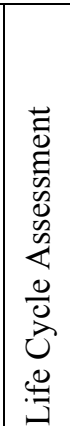 & $\sum_{\epsilon}$ & 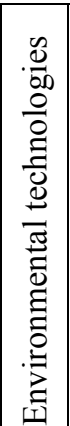 & 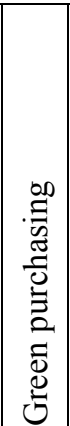 & 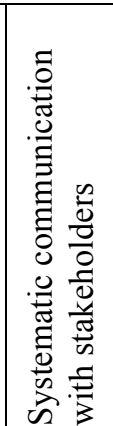 & 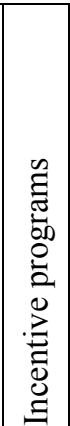 & 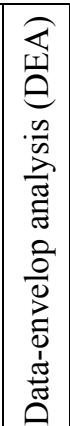 & $\begin{array}{l}0 \\
\frac{0}{0} \\
0 \\
0 \\
.0 \\
0 \\
0 \\
0 \\
0 \\
0 \\
0 \\
0 \\
0 \\
0\end{array}$ & 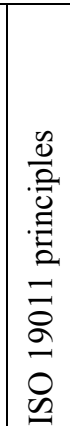 & 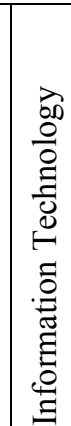 & 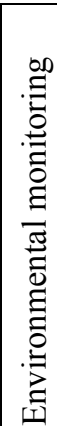 \\
\hline Alberti et al. 2000 & & & & $\mathrm{x}$ & & & & & & & & \\
\hline Aravind and Christmann 2011 & $\mathrm{x}$ & & & & & & & & & & & \\
\hline Bansal and Bogner 2002 & $\mathrm{x}$ & & & & & & & & & & & \\
\hline Bansal and Hunter 2003 & $\mathrm{x}$ & & & & & & & & & & & \\
\hline Boiral 2011 & $\mathrm{x}$ & & & & & & & & & $\mathrm{x}$ & & \\
\hline Cagno, Micheli, and Trucco 2012 & & & & & & & & & & & & \\
\hline Corbett and Kirsch 2001 & $\mathrm{x}$ & & & & & & & & & & & \\
\hline De Olivera Matias and Coelho 2002 & $\mathrm{x}$ & & & & & & & & & & & \\
\hline Delmas 2001 & $\mathrm{x}$ & & & & & $\mathrm{x}$ & & & & & & \\
\hline Delmas and Montiel 2009 & $\mathrm{x}$ & & & & & & & & & & & \\
\hline Delmas and Toffel 2008 & $\mathrm{x}$ & & & & & & & & & & & \\
\hline Ferrón-Vílchez 2016 & 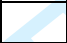 & & & & & & & & & & & $\mathrm{x}$ \\
\hline Gonzàlez-Benito and Gonzàlez-Benito 2005 & $\mathrm{x}$ & & & & & & & & & & & \\
\hline Gonzàlez-Benito and Gonzàlez-Benito 2008 & + & $\mathrm{x}$ & & & & & & & & & & \\
\hline González, Sarkis, and Adenso-Diaz 2008 & & $\mathrm{x}$ & & & & & & & & & & \\
\hline Hsu et al. 2013 & & $\mathrm{x}$ & 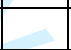 & 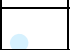 & $\mathrm{x}$ & & & & & & & \\
\hline Iatridis and Kesidou 2018 & $\mathrm{x}$ & & 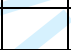 & & & & & & & & & \\
\hline Ivanova, Gray, and Sinha 2014 & & & $\mathrm{x}$ & De & & & & & & & $\mathrm{x}$ & \\
\hline King and Lenox 2001 & $\mathrm{x}$ & & 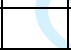 & 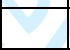 & & & & & & & & \\
\hline Kitazawa and Sarkis 2000 & $\mathrm{x}$ & & $\mathrm{x}$ & 8 & 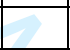 & & $\mathrm{x}$ & & & & & \\
\hline Kwon, Seo, and Seo 2002 & $\mathrm{x}$ & & $\mathrm{x}$ & & 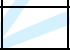 & & & & & & & $\mathrm{x}$ \\
\hline Li et al. 2010 & & $\mathrm{x}$ & & $\mathrm{x}$ & $\mathrm{x}$ & 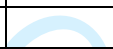 & & & & & & \\
\hline Link and Naveh 2006 & $\mathrm{x}$ & & & & & & & & & & & \\
\hline Lo, Yeung, and Cheng 2012 & $\mathrm{x}$ & $\mathrm{x}$ & & $\mathrm{x}$ & & 安 & & & & & & \\
\hline Melnyk, Sroufe, and Calantone 2002 & $\mathrm{x}$ & & & & & 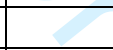 & 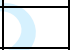 & & & & & \\
\hline Melnyk, Sroufe, and Calantone 2003a & $\mathrm{x}$ & & & & $\mathrm{x}$ & & & & & & & \\
\hline Miles, Munilla, and Russell 1997 & & $\mathrm{x}$ & & & & & 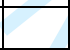 & & & & & \\
\hline Montiel and Husted 2009 & $\mathrm{x}$ & & & & & & 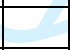 & & & & & \\
\hline Muskin 2000 & $\mathrm{x}$ & & & & & & $\mathrm{x}$ & & & & & \\
\hline Nakashima, Nose, Kuriyama 2006 & $\mathrm{x}$ & & & & & & & $\mathrm{x}$ & & & & \\
\hline Paulraj and De Jong 2011 & $\mathrm{x}$ & & & & & $\mathrm{x}$ & & & & & & \\
\hline Reynolds and Yuthas 2008 & $\mathrm{x}$ & & $\mathrm{x}$ & & & $\mathrm{x}$ & & & $\mathrm{x}$ & & & \\
\hline Schoenherr 2012 & $\mathrm{x}$ & & & & & & & & & & & \\
\hline Sullivan 2005 & $\mathrm{x}$ & & & & & & & & & & & \\
\hline Texeira 2012 & $\mathrm{x}$ & & & & & & & & & & & \\
\hline Vastag and Melnyk 2002 & $\mathrm{x}$ & & & & & & & & & & & \\
\hline \multicolumn{13}{|l|}{ Wilkinson and Dale 1999} \\
\hline Zhu et al. $2012 \mathrm{~b}$ & $\mathrm{x}$ & & & & & & & & & & & \\
\hline Zutshi and Sohal 2004a & $\mathrm{x}$ & & $\mathrm{x}$ & & & $\mathrm{x}$ & & & & & & \\
\hline Zutshi and Sohal 2004b & & & $\mathrm{x}$ & & & $\mathrm{x}$ & & & & & & \\
\hline TOTAL & 29 & 6 & 5 & 2 & 3 & 5 & $\mathbf{2}$ & $\mathbf{1}$ & 1 & 1 & 1 & 2 \\
\hline
\end{tabular}


Table 8: Impact on Performance (N: Negative; P: Positive; X: No Effect)

\begin{tabular}{|c|c|c|c|c|c|c|c|c|c|c|c|c|c|c|c|c|c|c|c|c|c|c|c|}
\hline & \multicolumn{8}{|c|}{ BUSINESS PROCESS } & \multicolumn{5}{|c|}{ FINANCIAL } & \multicolumn{4}{|c|}{ CUSTOMER } & \multicolumn{6}{|c|}{$\begin{array}{l}\text { LEARNING AND } \\
\text { GROWTH }\end{array}$} \\
\hline & 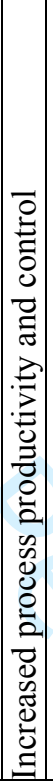 & 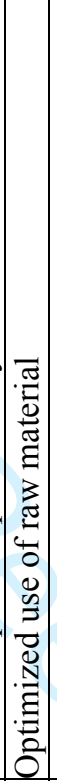 & 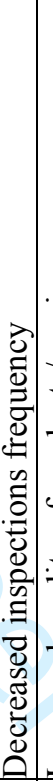 & 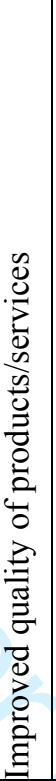 & 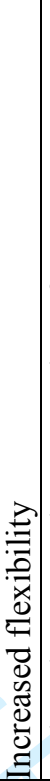 & 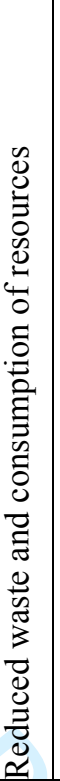 & 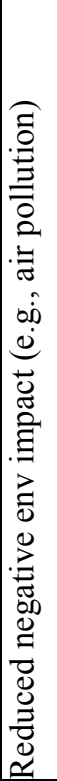 & 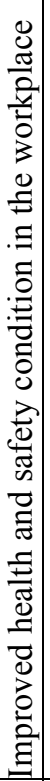 & 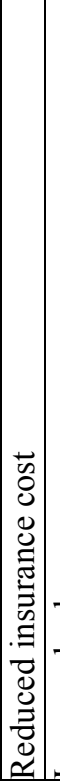 & . & 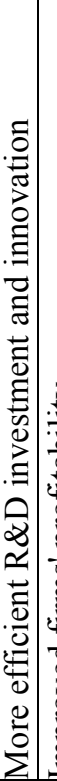 & 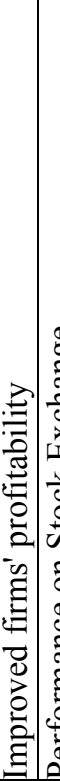 & 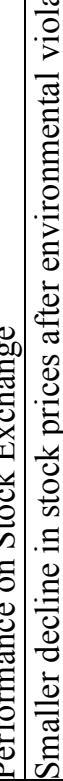 & 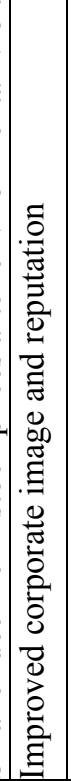 & 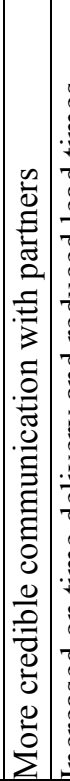 & 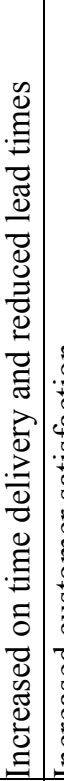 & 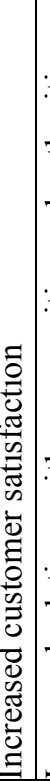 & 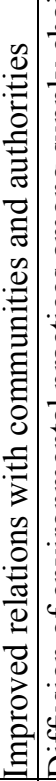 & 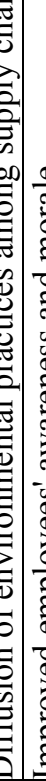 & 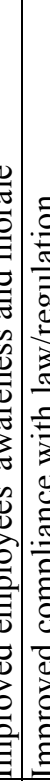 & 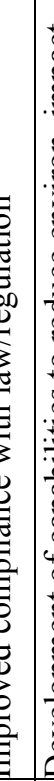 & 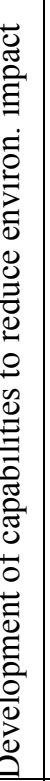 & 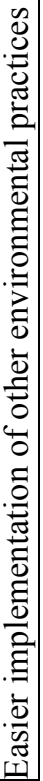 \\
\hline Alberti et al. 2000 & $\mathrm{P}$ & $\mathrm{P}$ & & & $\mathrm{P}$ & $\mathrm{P}$ & & & $\mathrm{P}$ & $\mathrm{P}$ & & & & $\mathrm{P}$ & & & & $\mathrm{P}$ & & & $P$ & & \\
\hline Aravind and Christmann 2011 & & & & & & A & & & & & & & & & & & & & & & & $\mathrm{P}$ & \\
\hline Arimura, Darnall, and Katayama 2010 & & & & & & 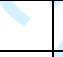 & 8 & & & & & & & & & & & & $P$ & & & & $\mathrm{P}$ \\
\hline Arimura et al. 2016 & & & & & & $\mathrm{P}$ & $\mathrm{P}$ & 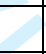 & & & & & & & & & & & & & & & \\
\hline Arnold 2015 & & & & & & & & & & & $\mathrm{P}$ & & & & & & & & & & & & \\
\hline Bansal and Bogner 2002 & $\mathrm{P}$ & & & & & $\mathrm{P}$ & & 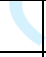 & 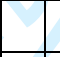 & 8 & & & & $\mathrm{P}$ & $\mathrm{P}$ & & & $\mathrm{P}$ & & & & & \\
\hline Bansal and Hunter 2003 & & & & $\mathrm{X}$ & & & & & + & P & & & & & & & & & & & & & \\
\hline Barla 2007 & & & & & & & & & & E & & & & & & & & & & & & $\mathrm{X}$ & \\
\hline Boiral 2007 & $\mathrm{P}$ & & & & & & & & & & & 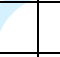 & & $\mathrm{P}$ & & & & 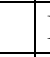 & 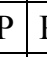 & 5 & & & \\
\hline Chiarini 2017 & & & & & & & & $\mathrm{P}$ & & & & $\overline{X X}$ & $\mathrm{X}$ & & & & $\mathrm{P}$ & $\mathrm{P}$ & $\mathrm{I}$ & 5 & & & \\
\hline Darnal and Kim 2012 & & & & & & $\mathrm{P}$ & & & & & & & & & & & & & & & & $\mathrm{P}$ & \\
\hline De Jong, Paulraj, and Blome 2014 & $\mathrm{P}$ & & & & & & & & & $\mathrm{P}$ & & $\mathrm{P}$ & & Pe & & & & & & & & & \\
\hline Delmas 2001 & $\mathrm{P}$ & & $\mathrm{P}$ & & & & & & $\mathrm{P}$ & & & $\mathrm{P}$ & & 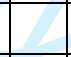 & D & & & & & & $p$ & & \\
\hline Ferrón-Vílchez 2016 & & & & & & & $\mathrm{P}$ & & & & & & & & & & & & & & & & \\
\hline Fryxell and Szeto 2002 & & & & & & & $\mathrm{P}$ & & & & & & & & & & & & & & & & \\
\hline $\begin{array}{l}\text { González-Benito and González-Benito } \\
2005\end{array}$ & & & & & & & & & & $\mathrm{P}$ & & & & & & & & & & & P & & \\
\hline González, Sarkis, and Adenso-Diaz 2008 & & & & & & & & & & & & & & & & & & - & $P$ & & & & $\mathrm{P}$ \\
\hline Graafland and Smid 2016 & & & & & & & $\mathrm{P}$ & $\mathrm{P}$ & & & & & & & & & & & & & & & \\
\hline He and Shen 2017 & & & & & & & & & & & $\mathrm{P}$ & & & & & & & & & & & & \\
\hline He, Yang, and Choi 2016 & & & $\mathrm{P}$ & & & & & & & & & & & & & & & $\mathrm{P}$ & & & $P$ & & \\
\hline $\begin{array}{l}\text { Heras-Saizarbitoria, Landín, and Molina- } \\
\text { Arzorín } 2011\end{array}$ & & & & & & $\mathrm{P}$ & & & & & & & & $P$ & $P$ & & & $\mathrm{P}$ & I & & $P$ & $P$ & \\
\hline
\end{tabular}


Table 8 (continued)

\begin{tabular}{|c|c|c|c|c|c|c|c|c|c|c|c|c|c|c|c|c|c|c|c|c|c|c|}
\hline & \multicolumn{8}{|c|}{ BUSINESS PROCESS } & \multicolumn{5}{|c|}{ FINANCIAL } & \multicolumn{4}{|c|}{ CUSTOMER } & \multicolumn{5}{|c|}{$\begin{array}{c}\text { LEARNING AND } \\
\text { GROWTH }\end{array}$} \\
\hline & 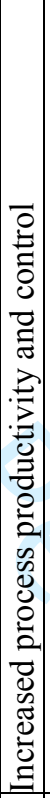 & 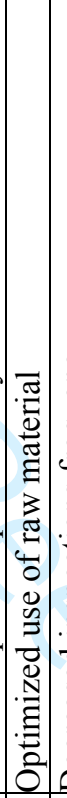 & 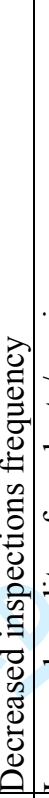 & 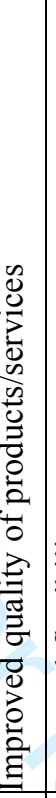 & 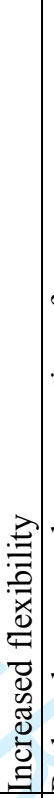 & 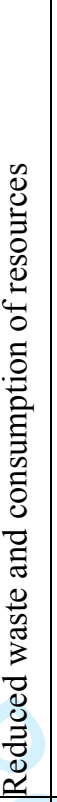 & 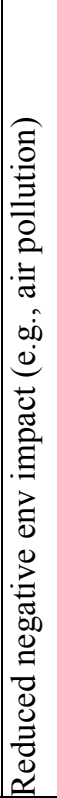 & 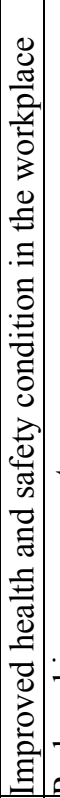 & 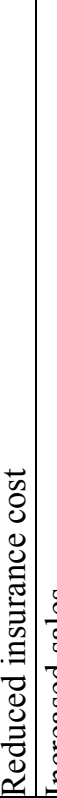 & 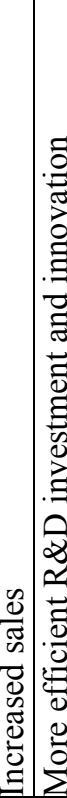 & 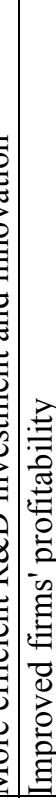 & 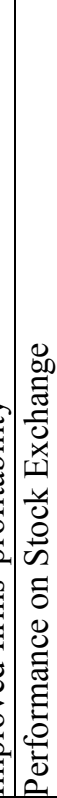 & 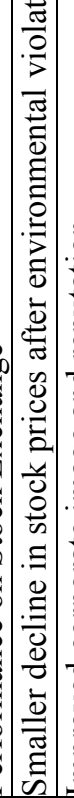 & 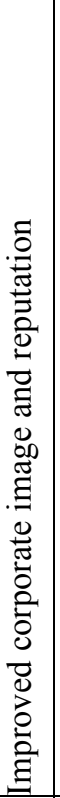 & 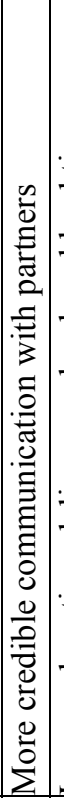 & 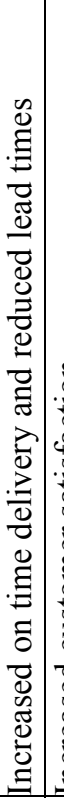 & 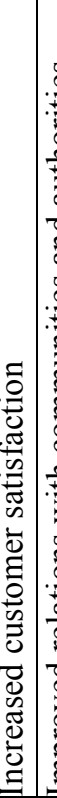 & 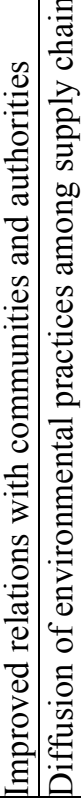 & 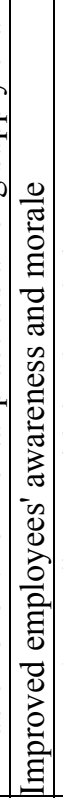 & 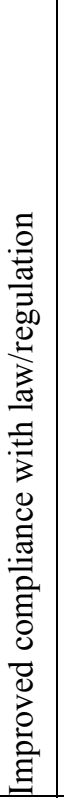 & 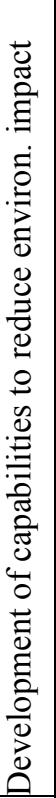 & 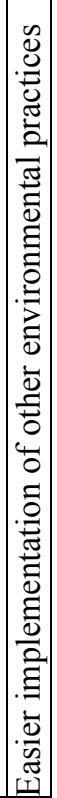 \\
\hline Inoue, Arimura, and Nakano 2013 & & & & & & A & & & & $\mathrm{P}$ & & & & & & & & & & & & \\
\hline Jacobs, Singhal, and Subramanian 2010 & & & & & & 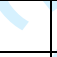 & Pre & & & $\mathrm{P}$ & & $\mathrm{P}$ & & & & & & & $\mathrm{P}$ & & & \\
\hline King, Lenox, and Terlaak 2005 & & & & & & & & & & & & & & & $\mathrm{P}$ & & & & & & & \\
\hline Kitazawa and Sarkis 2000 & & & & & & $\mathrm{P}$ & & & & & & & & & & & & & & & & \\
\hline Klassen and Vachon 2003 & & & & & & & & & & & & & & & & & & & & & & $\mathrm{P}$ \\
\hline Kwon, Seo, and Seo 2002 & & & & & & & $\mathrm{P}$ & & & & & & & & & & & & & & & \\
\hline Lim and Prakash 2014 & & & & & & & & & & $P$ & & & & & & & & & & & & \\
\hline Link and Naveh 2006 & & & & & & & & & & $\mathrm{X}$ & $\mathrm{X}$ & & & & & & & & & & $\mathrm{P}$ & \\
\hline Lo, Yeung, and Cheng 2012 & & $\mathrm{P} 1$ & $\mathrm{P}$ & & & $\mathrm{P}$ & & & & & $\mathrm{P}$ & & & & & & & & & $\mathrm{P}$ & $\mathrm{P}$ & \\
\hline McGuire 2014 & & & & & & & & & & & & 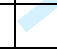 & & & & & & & & $\mathrm{P}$ & & \\
\hline Melnyk, Sroufe, and Calantone 2002 & & & & $\mathrm{P}$ & & $\mathrm{P}$ & & & & $\mathrm{P}$ & & & & $\mathrm{P}$ & & $\mathrm{P}$ & & & & & & \\
\hline Melnyk, Sroufe, and Calantone 2003a & & & & $\mathrm{P}$ & $\mathrm{P}$ & $\mathrm{P}$ & & & & & & & & 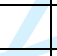 & L & $\mathrm{P}$ & & $\mathrm{P}$ & $\mathrm{P}$ & $\mathrm{P}$ & $\mathrm{P}$ & $P$ \\
\hline Mijatovic and Stokic 2010 & & & & & & & & & & & & & & & & & & & & & $\mathrm{P}$ & \\
\hline Miles, Munilla, and Russell 1997 & & & & & & $\mathrm{P}$ & & & & & & & & & & & & $\mathrm{P}$ & & & & \\
\hline Montiel, Husted, Christmann 2012 & & & & & & & & & & & & & & & $\mathrm{P}$ & & & & & & & \\
\hline Muskin 2000 & & & & & & & & & & $\mathrm{P}$ & & & & & & & & & & $\mathrm{P}$ & & \\
\hline Orsato 2006 & & & & & & & & & & & & & & $\mathrm{P}$ & & & & & & & $\mathrm{P}$ & \\
\hline Paulraj and de Jong 2011 & & & & & & & & & & & & $\mathrm{~N}$ & & & & & & & & & & \\
\hline Prajogo, Tang, and Lai 2014 & & & & & & & & & & & & & & & & & & & & & & $\mathrm{P}$ \\
\hline Schoenherr 2012 & & & & $\mathrm{P}$ & $\mathrm{P}$ & & & & & & & & & $\mathrm{P}$ & & $\mathrm{P}$ & $\mathrm{P}$ & & & & & \\
\hline
\end{tabular}


Table 8 (continued)

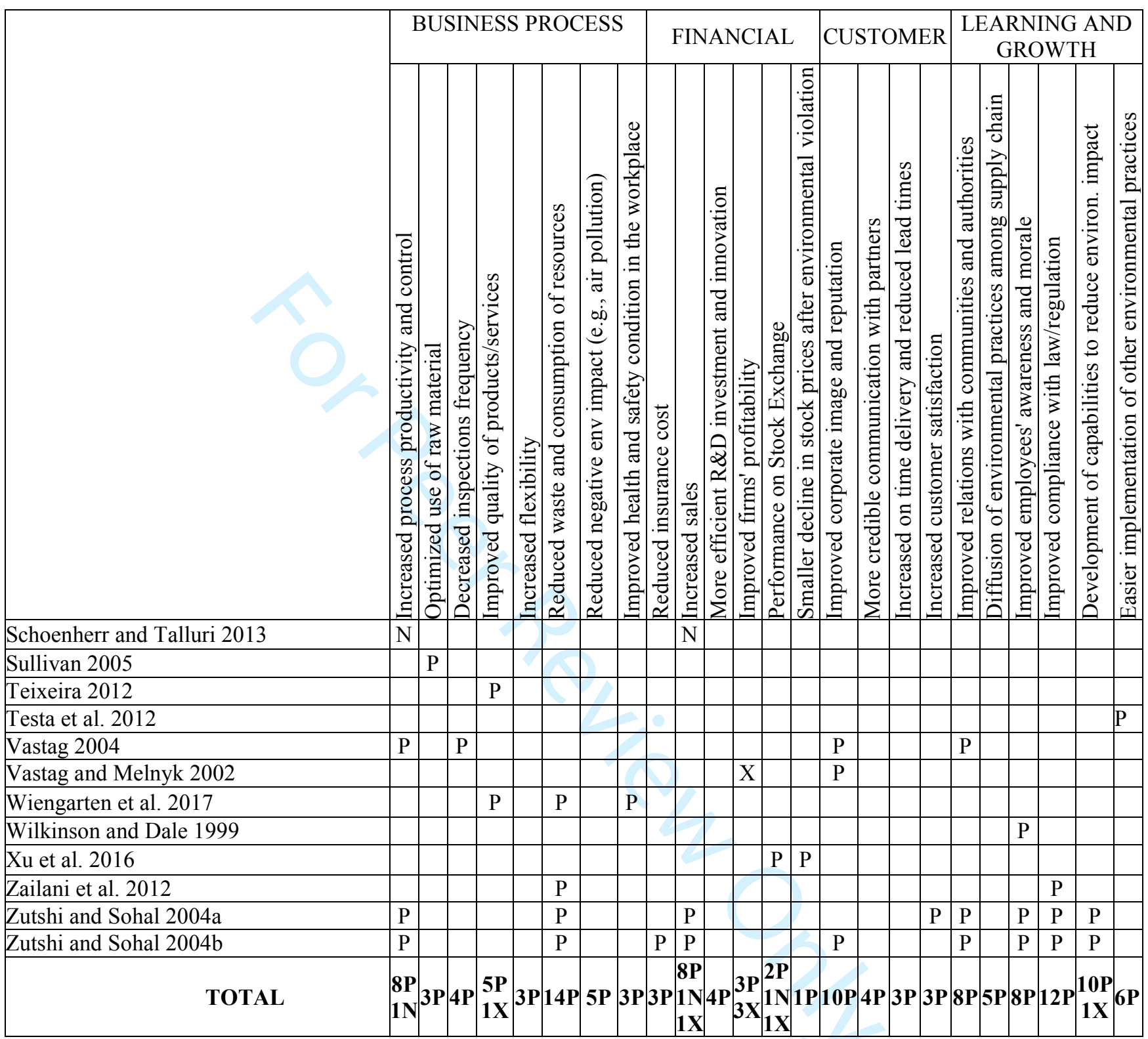


Table 9: Variables affecting the performance (P: Positive; X: No Effect; E: Effect)

\begin{tabular}{|c|c|c|c|c|c|c|c|c|c|c|c|c|c|c|c|c|c|}
\hline & 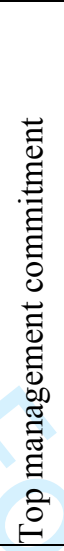 & 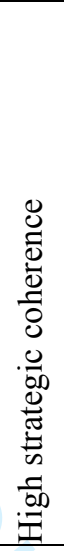 & 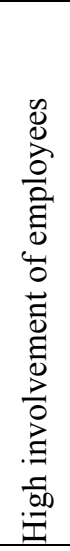 & 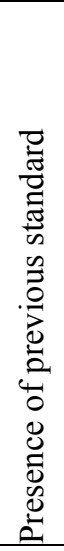 & 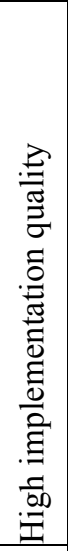 & 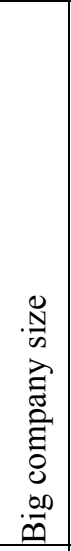 & 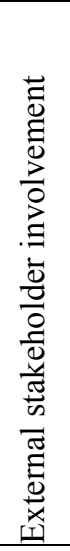 & 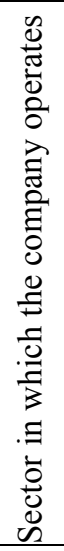 & 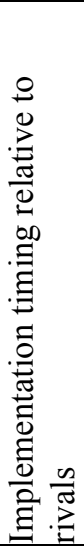 & 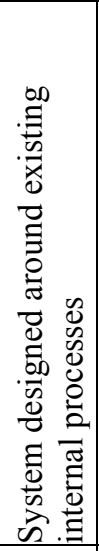 & 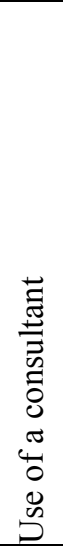 & 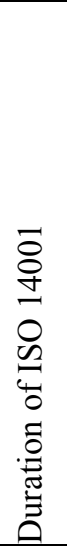 & 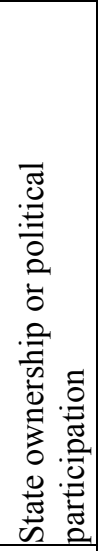 & 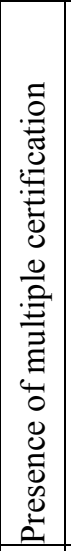 & 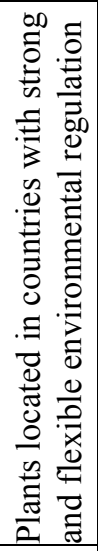 & 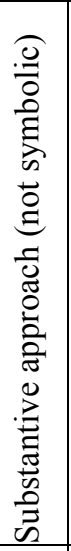 & 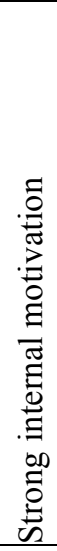 \\
\hline Aravind and Christmann 2011 & & $P$ & & & $\mathrm{P}$ & & & & & & & & & & & & \\
\hline Arimura et al. 2016 & & & T & & & & & & & & & & & & $\mathrm{P}$ & & \\
\hline Arnold 2015 & & 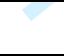 & 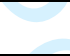 & & & & & & & & & $\mathrm{P}$ & & & & & \\
\hline Boiral 2011 & $\mathrm{P}$ & $\mathrm{P}$ & $\mathrm{P}$ & D & & & & & & & & & & & & & \\
\hline Boiral and Henri 2012 & & $\mathrm{P}$ & & A & & $\mathrm{X}$ & $\mathrm{P}$ & & & & & & & & & & \\
\hline Chiarini 2014 & & & & $\nabla$ & 8 & & & $\mathrm{E}$ & & & & & & & & & \\
\hline $\begin{array}{l}\text { De Jong, Paulraj, and Blome } \\
2014\end{array}$ & & $\mathrm{P}$ & & & $\mathrm{P}$ & & & & & & & & & & & & \\
\hline $\begin{array}{l}\text { De Oliveira Matias and Coelho } \\
2002\end{array}$ & & & & $\mathrm{P}$ & & & & & & & & & & & & & \\
\hline Delmas 2001 & & $\mathrm{P}$ & & & & & $\mathrm{P}$ & 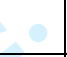 & & & & & & & & & \\
\hline Ferrón-Vílchez 2016 & & & & & & & $\mathrm{P}$ & 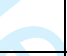 & & & & & & & & $\mathrm{P}$ & \\
\hline Fryxell and Szeto 2002 & & & & & & $\mathrm{P}$ & & 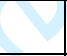 & 2 & & & & & & & & $\mathrm{P}$ \\
\hline He, Yang, and Choi 2016 & & & & & & & & 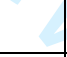 & 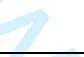 & & & & $\mathrm{E}$ & & & & \\
\hline $\begin{array}{l}\text { Heras-Saizarbitoria, Landín, and } \\
\text { Molina-Arzorín } 2011\end{array}$ & $\mathrm{P}$ & $\mathrm{P}$ & & & & & & & $C$ & & & & & & & & \\
\hline Iatridis and Kesidou 2018 & & & & & & & $\mathrm{P}$ & & & & & & & & & $\mathrm{P}$ & $\mathrm{P}$ \\
\hline Ivanova, Gray, and Sinha 2014 & $\mathrm{P}$ & & $\mathrm{P}$ & & & $\mathrm{X}$ & & & $\bar{X}$ & $\mathrm{P}$ & $\mathrm{X}$ & & & & & & $P$ \\
\hline Kitazawa and Sarkis 2000 & $\mathrm{P}$ & & $\mathrm{P}$ & & & & & & & & & & & & & & \\
\hline Lee et al. 2015 & & & & & & & $\mathrm{P}$ & & & & & 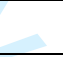 & & & & & \\
\hline Link and Naveh 2006 & & $\mathrm{P}$ & & & & & & & & & & & & & & & \\
\hline Paulraj and De Jong 2011 & & & & & & $\mathrm{P}$ & & & & & & & & & & & \\
\hline Schoenherr 2012 & & & & & & $\mathrm{P}$ & & & & & & & & & & & \\
\hline $\begin{array}{l}\text { Su, Dhanorkar, and Linderman } \\
2015\end{array}$ & & & & & & & & & $\mathrm{E}$ & & & & & & & & \\
\hline Testa et al. 2018 & & & & & & & $\mathrm{E}$ & & & & & & & & & $\mathrm{E}$ & \\
\hline Vastag and Melnyk 2002 & & & & & & & & $\mathrm{E}$ & & & & & & & & & \\
\hline Wiengarten et al. 2017 & & & & & & & & & & & & & & $\mathrm{E}$ & & & \\
\hline TOTAL & $4 \mathbf{P}$ & $7 \mathbf{P}$ & 3P & 1P & $2 P$ & \begin{tabular}{|l|}
$\mathbf{3 P}$ \\
$\mathbf{2 X}$ \\
\end{tabular} & $\begin{array}{l}\mathbf{5 P} \\
\mathbf{1 E} \\
\end{array}$ & $2 E$ & $\begin{array}{l}\mathbf{1 E} \\
\mathbf{1 X} \\
\end{array}$ & $\mathbf{1 P}$ & $1 \mathrm{X}$ & 1P & $1 \mathrm{E}$ & $1 \mathrm{E}$ & $\mathbf{1 P}$ & \begin{tabular}{|l|}
$\mathbf{2 P}$ \\
$\mathbf{1 E}$ \\
\end{tabular} & 3P \\
\hline
\end{tabular}


Table A1: Synthesis of the literature

\begin{tabular}{|c|c|c|c|c|c|c|c|c|c|c|c|c|c|c|c|c|}
\hline \multirow[b]{2}{*}{ 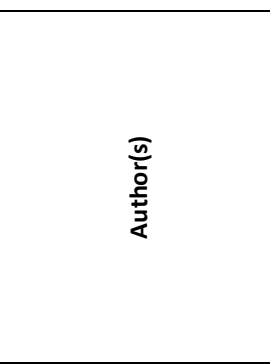 } & \multirow[b]{2}{*}{ 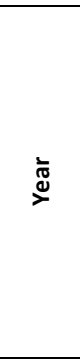 } & \multirow[b]{2}{*}{ 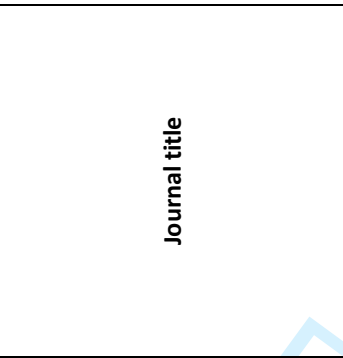 } & \multirow[b]{2}{*}{ 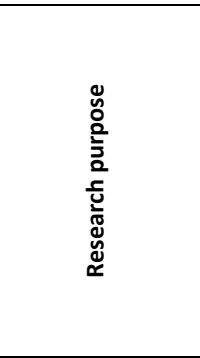 } & \multirow[b]{2}{*}{ 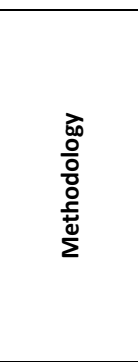 } & \multirow[b]{2}{*}{ 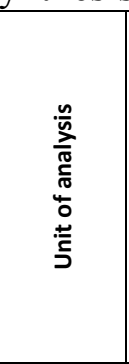 } & \multirow[b]{2}{*}{ 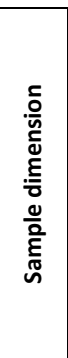 } & \multirow[b]{2}{*}{ 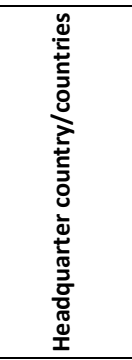 } & \multirow[b]{2}{*}{ 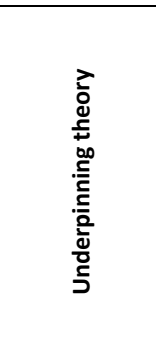 } & \multirow[b]{2}{*}{ 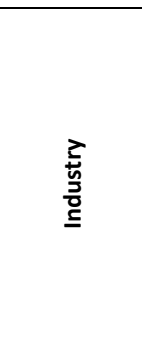 } & \multirow[b]{2}{*}{ 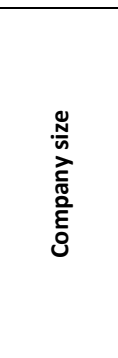 } & \multicolumn{3}{|c|}{ Antecedents } & \multirow[b]{2}{*}{ 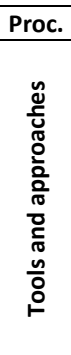 } & \multicolumn{2}{|c|}{ Consequences } \\
\hline & & & & & & & & & & & 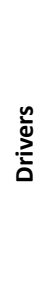 & 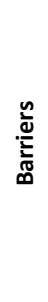 & 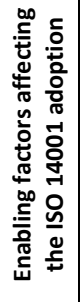 & & 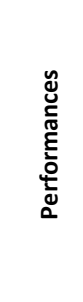 & 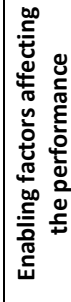 \\
\hline Alberti et al. & 2000 & $\begin{array}{l}\text { International Journal of } \\
\text { Production Research }\end{array}$ & exploration & survey & firm & 14 & Italy & - & $\begin{array}{c}\text { mainly } \\
\text { chemical }\end{array}$ & $\begin{array}{l}\text { medium } \\
\text { and large }\end{array}$ & $\mathbf{x}$ & $\mathbf{x}$ & $x$ & $\mathbf{x}$ & $x$ & \\
\hline Aravind and Christmann & 2011 & Business Ethics Quarterly & exploration & survey & plant & 144 & US & $\begin{array}{c}\text { Institutional } \\
\text { Theory }\end{array}$ & - & - & & & & $\mathrm{x}$ & $x$ & $x$ \\
\hline Arimura et al. & 2010 & $\begin{array}{l}\text { Journal of Environmental } \\
\text { Economics and Management }\end{array}$ & theory testing & survey & firm & 845 & Japan & - & - & - & & & & & $\mathrm{x}$ & \\
\hline Arimura et al. & 2016 & $\begin{array}{c}\text { Journal of Environmental } \\
\text { Management }\end{array}$ & theory building & survey & plant & $\begin{array}{c}141 \\
7\end{array}$ & $\begin{array}{l}\text { United } \\
\text { States, } \\
\text { Japan }\end{array}$ & - & - & - & & & & & $\mathrm{x}$ & $\mathrm{x}$ \\
\hline Arnold & 2015 & Ecological Economics & exploration & case study & firm & 110 & Germany & $\begin{array}{c}\text { Evolutionary } \\
\text { Theory }\end{array}$ & $\begin{array}{l}\text { water } \\
\text { industry }\end{array}$ & - & & & $x$ & & $x$ & $\mathbf{x}$ \\
\hline Baek & 2017 & Journal of Business Ethics & theory building & survey & firm & 982 & Korea & $\begin{array}{l}\text { Institutional } \\
\text { Theory, RBV }\end{array}$ & - & - & $\mathbf{x}$ & & $x$ & & & \\
\hline Bansal and Bogner & 2002 & Long Range Planning & theory building & conceptual & - & - & $\begin{array}{c}\text { Canada, } \\
\text { Japan, UK, } \\
\text { US }\end{array}$ & 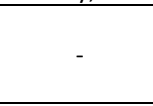 & - & - & $\mathrm{x}$ & $\mathbf{x}$ & $\mathrm{x}$ & $\mathbf{x}$ & $\mathrm{x}$ & \\
\hline Bansal and Hunter & 2003 & Journal of Business Ethics & exploration & simulation & firm & 46 & US & - & - & - & & & $\mathbf{x}$ & $\mathbf{x}$ & $\mathbf{x}$ & \\
\hline Barla & 2007 & $\begin{array}{l}\text { Journal of Environmental } \\
\text { Economics and Management }\end{array}$ & theory testing & case study & firm & 37 & Quebec & 0 & $\begin{array}{l}\text { pulp and } \\
\text { paper }\end{array}$ & - & & & & & $\mathrm{x}$ & \\
\hline Boiral & 2007 & Organization Science & exploration & case study & firm & 9 & Canada & $\begin{array}{l}\text { Institutional } \\
\text { Theory, } \\
\text { Rhetorical } \\
\text { Theory of } \\
\text { Diffusion }\end{array}$ & - & $\begin{array}{l}\text { medium } \\
\text { and large }\end{array}$ & & $x$ & & & $x$ & \\
\hline Boiral & 2011 & Long Range Planning & exploration & $\begin{array}{l}\text { conceptual } \\
\text {, interview }\end{array}$ & individual & 189 & Canada & - & & - & & $\mathbf{x}$ & & $\mathbf{x}$ & & $x$ \\
\hline Boiral and Henri & 2012 & $\begin{array}{c}\text { Journal of Environmental } \\
\text { Management }\end{array}$ & theory building & survey & firm & 303 & Canada & - & - & - & & & & & & $\mathbf{x}$ \\
\hline Cagno et al. & 2012 & Production Planning \& Control & theory building & case study & firm & 1 & Italy & - & $\begin{array}{c}\text { electro- } \\
\text { mechanical }\end{array}$ & medium & & & & $\mathrm{x}$ & & \\
\hline Chiarini & 2014 & $\begin{array}{c}\text { Business Stategy and the } \\
\text { Environment }\end{array}$ & theory building & survey & firm & 800 & Europe & - & - & large & & & & & & $\mathbf{x}$ \\
\hline Chiarini & 2017 & $\begin{array}{c}\text { Business Stategy and the } \\
\text { Environment }\end{array}$ & theory testing & survey & firm & 164 & Europe & - & - & $\begin{array}{l}\text { medium } \\
\text { and large }\end{array}$ & $\mathbf{x}$ & $\mathbf{x}$ & & & $x$ & \\
\hline Corbett and Kirsch & 2001 & $\begin{array}{c}\text { Production and Operations } \\
\text { Management }\end{array}$ & theory building & simulation & - & - & - & - & - & - & $\mathbf{x}$ & & $\mathbf{x}$ & $\mathrm{x}$ & & \\
\hline Corbett and Kirsch & 2004 & $\begin{array}{c}\text { Production and Operations } \\
\text { Management }\end{array}$ & exploration & conceptual & - & - & - & - & - & - & & & $\mathrm{x}$ & & & \\
\hline Darnal and Kim & 2012 & Public Administration Review & theory building & survey & firm & $\begin{array}{c}418 \\
7 \\
\end{array}$ & $\begin{array}{l}\text { US, Japan, } \\
\text { Europe }\end{array}$ & - & - & $\begin{array}{l}\text { medium } \\
\text { and large }\end{array}$ & & & & & $\mathbf{x}$ & \\
\hline
\end{tabular}




\begin{tabular}{|c|c|c|c|c|c|c|c|c|c|c|c|c|c|c|c|c|}
\hline \multirow[b]{2}{*}{$\begin{array}{l}\bar{n} \\
\frac{n}{0} \\
\frac{c}{5} \\
\frac{1}{4}\end{array}$} & \multirow[b]{2}{*}{ 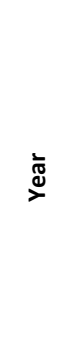 } & \multirow[b]{2}{*}{ 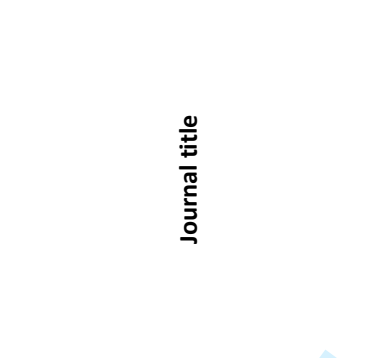 } & \multirow[b]{2}{*}{ 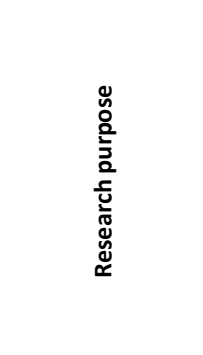 } & \multirow[b]{2}{*}{ 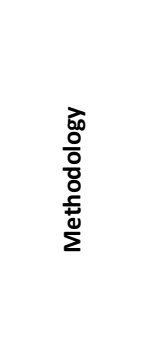 } & \multirow[b]{2}{*}{$\begin{array}{l}\frac{n}{4} \\
\frac{n}{20} \\
\frac{\pi}{\pi} \\
\frac{\pi}{0} \\
0 \\
\frac{.1}{5} \\
5\end{array}$} & \multirow[b]{2}{*}{ 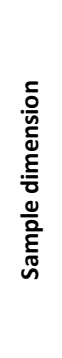 } & \multirow[b]{2}{*}{ 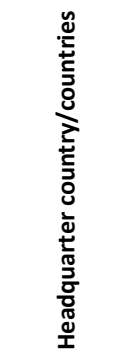 } & \multirow[b]{2}{*}{ 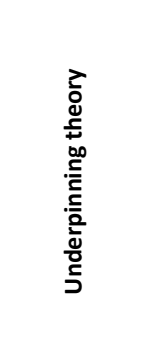 } & \multirow[b]{2}{*}{ 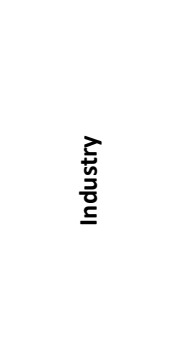 } & \multirow[b]{2}{*}{ 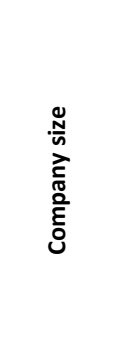 } & \multicolumn{3}{|c|}{ Antecedents } & \multirow[b]{2}{*}{ 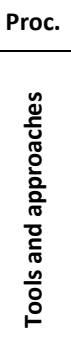 } & \multicolumn{2}{|c|}{ Consequences } \\
\hline & & & & & & & & & & & 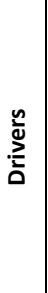 & 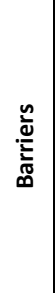 & 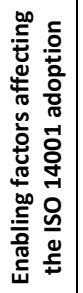 & & 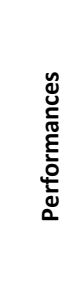 & 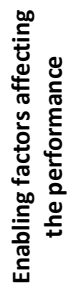 \\
\hline De Jong et al. & 2013 & Journal of Business Ethics & theory building & simulation & firm & 219 & US & - & - & - & & & & & $\mathbf{x}$ & $\mathbf{x}$ \\
\hline $\begin{array}{l}\text { De Olivera Matias and } \\
\text { Coelho }\end{array}$ & 2002 & $\begin{array}{l}\text { International Journal of } \\
\text { Production Research }\end{array}$ & exploration & conceptual & - & - & - & - & - & - & & & & $\mathrm{x}$ & & $\mathrm{x}$ \\
\hline Del Brìo and Junquera & 2003 & $\begin{array}{l}\text { International Journal of } \\
\text { Production Research }\end{array}$ & theory testing & survey & firm & 373 & Spanish & - & - & $\begin{array}{l}\text { medium } \\
\text { and large }\end{array}$ & $\mathbf{x}$ & $\mathbf{x}$ & $\mathrm{x}$ & & & \\
\hline Delmas & 2001 & $\begin{array}{c}\text { Production and Operations } \\
\text { Management }\end{array}$ & exploration & conceptual & individual & 55 & US & RBV & - & - & & $\mathbf{x}$ & & $\mathbf{x}$ & $\mathbf{x}$ & $\mathbf{x}$ \\
\hline $\begin{array}{l}\text { Delmas and Montes- } \\
\text { Sancho }\end{array}$ & 2011 & Business Ethics Quarterly & theory extention & conceptual & - & - & - & $\begin{array}{l}\text { Institutional } \\
\text { Theory } \\
\end{array}$ & - & - & $\mathbf{x}$ & & $\mathrm{x}$ & & & \\
\hline Delmas and Montiel & 2009 & $\begin{array}{l}\text { Journal of Economics \& } \\
\text { Management Strategy }\end{array}$ & theory testing & survey & supplier & $\begin{array}{c}315 \\
2\end{array}$ & $\begin{array}{l}\text { Europe, } \\
\text { Japan, US }\end{array}$ & $\begin{array}{c}\text { TCE, } \\
\text { Signalling } \\
\text { Theory }\end{array}$ & automotive & - & $\mathbf{x}$ & & $x$ & $\mathbf{x}$ & & \\
\hline Delmas and Toffel & 2008 & Strategic Management Journal & theory extentiom & survey & plant & 536 & US & $\begin{array}{l}\text { Institutional } \\
\text { and Neo- } \\
\text { Institutional } \\
\text { theory }\end{array}$ & - & - & $x$ & & $x$ & $\mathbf{x}$ & & \\
\hline Ferrón-Vílchez & 2016 & $\begin{array}{l}\text { Journal of Environmental } \\
\text { Management }\end{array}$ & theory building & survey & firm & $\begin{array}{c}121 \\
4\end{array}$ & $\begin{array}{c}\text { Canada, } \\
\text { France, } \\
\text { Germany, } \\
\text { Hungary, } \\
\text { Japan, } \\
\text { Norway, } \\
\text { USA }\end{array}$ & & - & - & & $x$ & & $x$ & $x$ & $\mathrm{x}$ \\
\hline Fryxell and Szeto & 2002 & $\begin{array}{c}\text { Journal of Environmental } \\
\text { Management }\end{array}$ & theory testing & survey & firm & 29 & China & & - & - & $\mathbf{x}$ & & & & $\mathrm{x}$ & $\mathrm{x}$ \\
\hline Gonzàlez et al. & 2008 & $\begin{array}{l}\text { International Journal of } \\
\text { Operations \& Production } \\
\text { Management }\end{array}$ & exploration & survey & supplier & 157 & Spanish & $\begin{array}{l}\text { Institutional, } \\
\text { RBV, } \\
\text { Stakeholder } \\
\text { Theory }\end{array}$ & automotive & $\begin{array}{l}\text { stratified } \\
\text { sample }\end{array}$ & $x$ & & & $\mathrm{x}$ & $\mathrm{x}$ & \\
\hline $\begin{array}{l}\text { Gonzàlz-Benito and } \\
\text { Gonzalez Benito }\end{array}$ & 2005 & British Journal of Management & theory building & survey & firm & 184 & Spanish & - & $\begin{array}{c}\text { chemical, } \\
\text { electonics and } \\
\text { electrical, } \\
\text { furniture and } \\
\text { fixtures } \\
\end{array}$ & $\begin{array}{l}\text { medium } \\
\text { and large }\end{array}$ & $\mathbf{x}$ & & $\mathrm{x}$ & $\mathrm{x}$ & $\mathrm{x}$ & \\
\hline $\begin{array}{l}\text { Gonzàlz-Benito and } \\
\text { Gonzalez Benito }\end{array}$ & 2008 & $\begin{array}{l}\text { International Journal of } \\
\text { Production Economics }\end{array}$ & exploration & survey & firm & 184 & Spanish & - & $\begin{array}{l}\text { chemical, } \\
\text { electonics and } \\
\text { electrical, } \\
\text { furniture and } \\
\text { fixtures }\end{array}$ & $\begin{array}{l}\text { medium } \\
\text { and large }\end{array}$ & $x$ & & $x$ & $\mathrm{x}$ & & \\
\hline Graafland and Smid & 2016 & $\begin{array}{c}\text { Corporate Social Responsibility } \\
\text { and Environmental Management }\end{array}$ & theory building & survey & firm & $\begin{array}{c}520 \\
5\end{array}$ & Europe & - & - & $\begin{array}{c}\text { small and } \\
\text { medium }\end{array}$ & & & $\mathbf{x}$ & & $\mathbf{x}$ & \\
\hline
\end{tabular}




\begin{tabular}{|c|c|c|c|c|c|c|c|c|c|c|c|c|c|c|c|c|}
\hline \multirow[b]{2}{*}{ 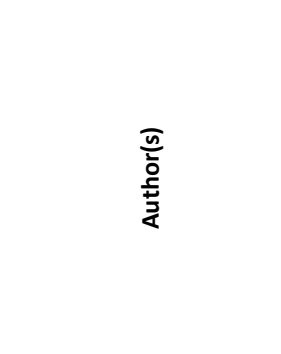 } & \multirow[b]{2}{*}{$\stackrel{\varpi}{\searrow}$} & \multirow[b]{2}{*}{ 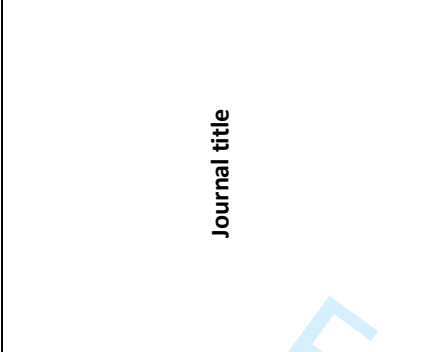 } & \multirow[b]{2}{*}{ 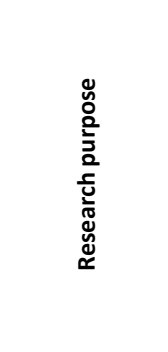 } & \multirow[b]{2}{*}{ 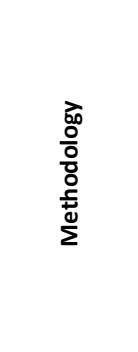 } & \multirow[b]{2}{*}{$\begin{array}{l}\frac{n}{n} \\
\frac{n}{\pi} \\
\frac{0}{\pi} \\
\frac{\pi}{0} \\
\frac{ \pm}{5} \\
5\end{array}$} & \multirow[b]{2}{*}{ 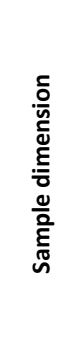 } & \multirow[b]{2}{*}{ 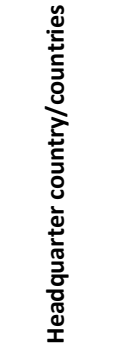 } & \multirow[b]{2}{*}{ 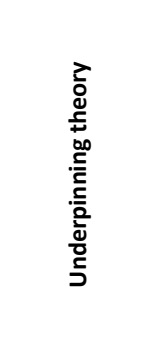 } & \multirow[b]{2}{*}{ 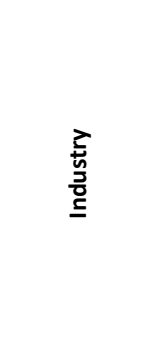 } & \multirow[b]{2}{*}{ 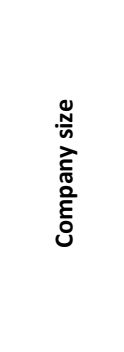 } & \multicolumn{3}{|c|}{ Antecedents } & \multirow[b]{2}{*}{ 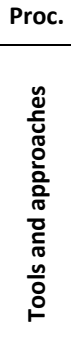 } & \multicolumn{2}{|c|}{ Consequences } \\
\hline & & & & & & & & & & & 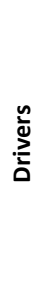 & 商 & 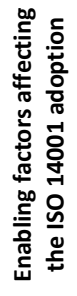 & & 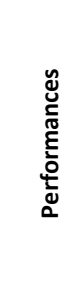 & 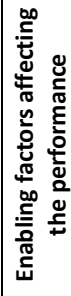 \\
\hline Gupta and Innes & 2014 & $\begin{array}{c}\text { Journal of Environmental Economics } \\
\text { and Management }\end{array}$ & $\begin{array}{l}\text { theory } \\
\text { building }\end{array}$ & survey & firm & 823 & $\begin{array}{l}\text { United } \\
\text { States }\end{array}$ & - & - & large & $\mathbf{x}$ & & $\mathbf{x}$ & & & \\
\hline He and Shen & 2017 & Journal of Business Ethics & $\begin{array}{c}\text { theory } \\
\text { building } \\
\end{array}$ & survey & firm & 770 & China & RBV & - & - & & & & & $\mathrm{x}$ & \\
\hline He et al. & 2016 & Journal of Business Ethics & $\begin{array}{l}\text { theory } \\
\text { building }\end{array}$ & survey & firm & 2312 & China & $\begin{array}{l}\text { Institutional } \\
\text { Theory }\end{array}$ & - & - & & & $\mathbf{x}$ & & $\mathbf{x}$ & $\mathbf{x}$ \\
\hline Heras-Saizarbitoria et al. & 2011 & $\begin{array}{c}\text { International Journal of Operations \& } \\
\text { Production Management } \\
\end{array}$ & theory testing & LR, survey & firm & 214 & Spanish & $\begin{array}{c}\text { Institutional } \\
\text { Theory }\end{array}$ & - & - & $\mathbf{x}$ & & $\mathbf{x}$ & & $\mathbf{x}$ & $\mathbf{x}$ \\
\hline Hsu et al. & 2013 & $\begin{array}{c}\text { International Journal of Operations \& } \\
\text { Production Management }\end{array}$ & theory testing & survey & firm & 132 & Malaysia & $\begin{array}{l}\text { Institutional } \\
\text { Theory }\end{array}$ & - & - & $\mathbf{x}$ & & & $x$ & & \\
\hline Husted et al. & 2016 & \begin{tabular}{|l|} 
Journal of International Business \\
Studies
\end{tabular} & theory testing & survey & plant & 451 & Mexico & $\begin{array}{c}\text { Istitutional } \\
\text { Theory }\end{array}$ & automotive & - & $\mathbf{x}$ & & $\mathbf{x}$ & & & \\
\hline latridis and Kesidou & 2018 & Journal of Business Ethics & theory testing & case study & firm & 45 & Greece & - & - & $\begin{array}{c}\text { small and } \\
\text { medium }\end{array}$ & $\mathbf{x}$ & $\mathbf{x}$ & & $\mathbf{x}$ & & $\mathbf{x}$ \\
\hline Inoue et al. & 2013 & Ecological Economics & theory testing & survey & firm & 1499 & Japan & - & - & - & & & & & $\mathbf{x}$ & \\
\hline Ivanova et al. & 2014 & $\begin{array}{c}\text { International Journal of Operations \& } \\
\text { Production Management }\end{array}$ & $\begin{array}{l}\text { theory } \\
\text { building }\end{array}$ & case study & plant & 10 & $\begin{array}{l}\text { United } \\
\text { States }\end{array}$ & - & - & - & & & & $\mathbf{x}$ & & $\mathrm{x}$ \\
\hline Jacobs et al. & 2010 & Journal of Operations Management & $\begin{array}{l}\text { theory } \\
\text { extention }\end{array}$ & case study & - & 780 & - & - & - & - & & $\mathbf{x}$ & $x$ & & $\mathbf{x}$ & \\
\hline Jiang and Bansal & 2003 & Journal of Management Studies & $\begin{array}{l}\text { theory } \\
\text { building }\end{array}$ & conceptual & - & 16 & Canada & $\begin{array}{c}\text { Institutional } \\
\text { Theory }\end{array}$ & $\begin{array}{c}\text { pulp and } \\
\text { paper }\end{array}$ & - & $\mathbf{x}$ & $\mathbf{x}$ & $\mathbf{x}$ & & & \\
\hline Johnstone and Labonne & 2008 & Ecological Economics & $\begin{array}{l}\text { theory } \\
\text { building }\end{array}$ & case study & firm & 4000 & $\begin{array}{c}\text { Europe, } \\
\text { Japan, } \\
\text { US }\end{array}$ & - & - & $\begin{array}{l}\text { medium } \\
\text { and large }\end{array}$ & $\mathbf{x}$ & & & & & \\
\hline King and Lenox & 2001 & $\begin{array}{c}\text { Production and Operations } \\
\text { Management }\end{array}$ & theory testing & simulation & plant & $\begin{array}{c}1749 \\
9\end{array}$ & US & - & - & - & & & $\mathrm{x}$ & $\mathbf{x}$ & & \\
\hline King et al. & 2005 & Academy of Management Journal & $\begin{array}{l}\text { theory } \\
\text { extention }\end{array}$ & simulation & dyad & 7899 & US & $\begin{array}{c}\text { Neo- } \\
\text { Institutional } \\
\text { Theory } \\
\end{array}$ & - & - & $\mathbf{x}$ & & $\mathbf{x}$ & & $\mathbf{x}$ & \\
\hline Kitazawa and Sarkis & 2000 & $\begin{array}{c}\text { International Journal of Operations \& } \\
\text { Production Management }\end{array}$ & exploration & case study & firm & 3 & US & - & - & large & & $\mathbf{x}$ & & & $\mathrm{x}$ & $\mathrm{x}$ \\
\hline Klassen and Vachon & 2003 & $\begin{array}{c}\text { Production and Operations } \\
\text { Management }\end{array}$ & exploration & survey & plant & 202 & Canada & - & - & - & & & $\mathrm{x}$ & & $\mathbf{x}$ & \\
\hline Kwon, Seo and Seo & 2002 & $\begin{array}{c}\text { Journal of Environmental } \\
\text { Management }\end{array}$ & theory testing & survey & firm & 138 & Korea & - & - & - & $\mathbf{x}$ & & & $\mathrm{x}$ & $\mathbf{x}$ & \\
\hline Lee et al. & 2015 & Production Planning and Control & theory testing & survey & firm & 119 & Malaysia & - & - & - & & & & & & $\mathbf{x}$ \\
\hline Lim and Prakash & 2014 & Public Administration Review & theory testing & case study & plant & 79 & $\begin{array}{c}\text { US, } \\
\text { Japan, } \\
\text { Europe }\end{array}$ & - & - & - & & & & & $\mathbf{x}$ & \\
\hline
\end{tabular}




\begin{tabular}{|c|c|c|c|c|c|c|c|c|c|c|c|c|c|c|c|c|}
\hline \multirow[b]{2}{*}{$\begin{array}{l}\bar{n} \\
\frac{n}{0} \\
\frac{c}{5} \\
\frac{3}{4}\end{array}$} & \multirow[b]{2}{*}{$\stackrel{\frac{1}{\varpi}}{\searrow}$} & \multirow[b]{2}{*}{ 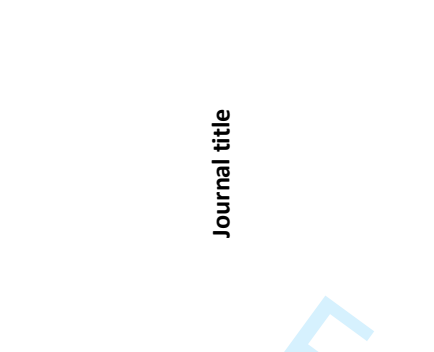 } & \multirow[b]{2}{*}{ 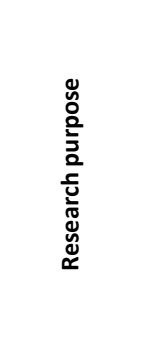 } & \multirow[b]{2}{*}{ 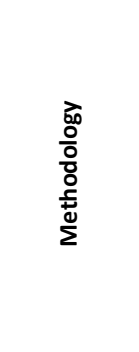 } & \multirow[b]{2}{*}{$\begin{array}{l}\frac{n}{0} \\
\frac{n}{\pi} \\
\frac{\pi}{\pi} \\
\frac{\pi}{0} \\
\frac{ \pm}{5} \\
5\end{array}$} & \multirow[b]{2}{*}{ 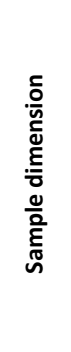 } & \multirow[b]{2}{*}{ 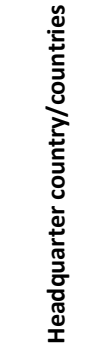 } & \multirow[b]{2}{*}{ 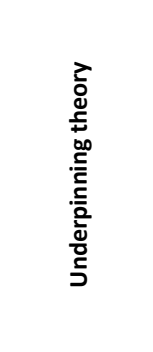 } & \multirow[b]{2}{*}{ 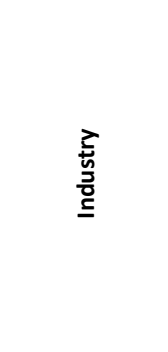 } & \multirow[b]{2}{*}{ 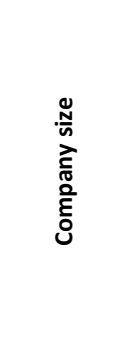 } & \multicolumn{3}{|c|}{ Antecedents } & \multirow[b]{2}{*}{ 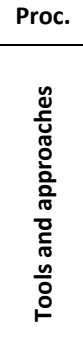 } & \multicolumn{2}{|c|}{ Consequences } \\
\hline & & & & & & & & & & & $\stackrel{n}{\stackrel{n}{ \pm}}$ & 峁 & 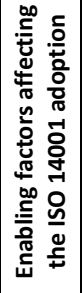 & & 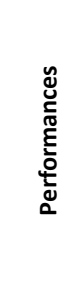 & 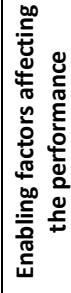 \\
\hline Link and Naveh & 2006 & $\begin{array}{l}\text { IEEE Transactions on Engineering } \\
\text { Management }\end{array}$ & $\begin{array}{l}\text { theory } \\
\text { building }\end{array}$ & survey & firm & 40 & Israel & - & $\begin{array}{l}\text { chemical, hi- } \\
\text { tech, food and } \\
\text { beverages, } \\
\text { services } \\
\text { sector } \\
\end{array}$ & $\begin{array}{c}\text { medium } \\
\text { and large }\end{array}$ & & & & & $\mathbf{x}$ & $\mathbf{x}$ \\
\hline Lo et al. & 2012 & $\begin{array}{c}\text { International Journal of Production } \\
\text { Economics } \\
\end{array}$ & exploration & case study & firm & 61 & US & - & $\begin{array}{c}\text { fashion and } \\
\text { textile }\end{array}$ & - & & & & $\mathbf{x}$ & $\mathbf{x}$ & \\
\hline McGuire & 2014 & Ecological Economics & $\begin{array}{l}\text { theory } \\
\text { testing }\end{array}$ & survey & firm & 1268 & China & - & - & - & $\mathbf{x}$ & & & & $x$ & $\mathbf{x}$ \\
\hline Melnyk et al. & 2002 & $\begin{array}{l}\text { International Journal of Production } \\
\text { Research }\end{array}$ & exploration & survey & individual & 1510 & US & - & - & - & & & & $\mathbf{x}$ & $\mathbf{x}$ & \\
\hline Melnyk et al. & $2003 a$ & $\begin{array}{c}\text { Production and Operations } \\
\text { Management }\end{array}$ & $\begin{array}{l}\text { theory } \\
\text { building }\end{array}$ & survey & individual & 1453 & US & - & - & - & $\mathbf{x}$ & $\mathbf{x}$ & $\mathbf{x}$ & & & \\
\hline Melnyk et al. & $2003 b$ & Journal of Operations Management & exploration & survey & individual & 1222 & $\begin{array}{c}\text { North } \\
\text { America }\end{array}$ & - & - & - & & & & $\mathbf{x}$ & $\mathbf{x}$ & \\
\hline Mijatovic and Stokic & 2010 & Journal of Business Ethics & exploration & survey & firm & 122 & Serbia & - & - & - & & & & & $\mathbf{x}$ & \\
\hline Miles et al. & 1997 & Industrial Marketing Management & exploration & conceptual & - & - & - & - & - & - & $\mathbf{x}$ & & $\mathbf{x}$ & $\mathbf{x}$ & $\mathbf{x}$ & \\
\hline Montiel and Husted & 2009 & Journal of Business Ethics & $\begin{array}{l}\text { theory } \\
\text { extention }\end{array}$ & simulation & plant & 1328 & Mexico & - & - & - & & & $\mathbf{x}$ & $\mathbf{x}$ & & \\
\hline Montiel et al. & 2012 & Strategic Management Journal & $\begin{array}{l}\text { theory } \\
\text { testing }\end{array}$ & conceptual & supplier & 433 & Mexico & $\begin{array}{l}\text { TCE, } \\
\text { Institutional } \\
\text { Theory, } \\
\text { Signaling } \\
\text { Theory }\end{array}$ & automotive & $\begin{array}{l}\text { stratified } \\
\text { sample }\end{array}$ & $\mathbf{x}$ & $\mathbf{x}$ & $\mathbf{x}$ & & $\mathbf{x}$ & \\
\hline Muskin & 2000 & Journal of Business Ethics & $\begin{array}{l}\text { theory } \\
\text { building }\end{array}$ & conceptual & - & - & - & - & - & - & & & & $\mathbf{x}$ & $\mathbf{x}$ & \\
\hline Nakamura et al. & 2000 & $\begin{array}{l}\text { Journal of Environmental Economics } \\
\text { and Management }\end{array}$ & $\begin{array}{l}\text { theory } \\
\text { testing }\end{array}$ & survey & firm & 193 & Japan & - & - & - & & & $\mathbf{x}$ & & & \\
\hline Nakashima et al. & 2006 & $\begin{array}{l}\text { International Journal of Production } \\
\text { Research }\end{array}$ & $\begin{array}{l}\text { theory } \\
\text { building }\end{array}$ & conceptual & firm & 14 & Japan & - & $\begin{array}{l}\text { consumer } \\
\text { electronics, } \\
\text { automotive }\end{array}$ & - & & & & $\mathbf{x}$ & & \\
\hline Neves et al. & 2017 & Journal of Environmental Management & esploration & survey & - & - & - & - & - & - & $\mathbf{x}$ & & $x$ & & & \\
\hline Nishitani & 2008 & Ecological Economics & $\begin{array}{l}\text { theory } \\
\text { building }\end{array}$ & case study & firm & 433 & Japan & - & - & - & & & $x$ & & & \\
\hline Orsato & 2006 & California Management Review & exploration & conceptual & - & - & - & RBV & - & - & $\mathbf{x}$ & $\mathbf{x}$ & & & $\mathbf{x}$ & \\
\hline Paulraj and De Jong & 2011 & $\begin{array}{c}\text { International Journal of Operations \& } \\
\text { Production Management }\end{array}$ & $\begin{array}{l}\text { theory } \\
\text { testing }\end{array}$ & case study & firm & 140 & US & - & - & - & & & & $\mathbf{x}$ & $\mathbf{x}$ & $\mathbf{x}$ \\
\hline
\end{tabular}

\section{5}

URL: https://mc.manuscriptcentral.com/qmj 


\begin{tabular}{|c|c|c|c|c|c|c|c|c|c|c|c|c|c|c|c|c|}
\hline \multirow[b]{2}{*}{$\begin{array}{l}\bar{n} \\
\frac{n}{0} \\
\frac{c}{5} \\
\frac{3}{4}\end{array}$} & \multirow[b]{2}{*}{ 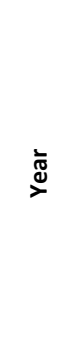 } & \multirow[b]{2}{*}{ 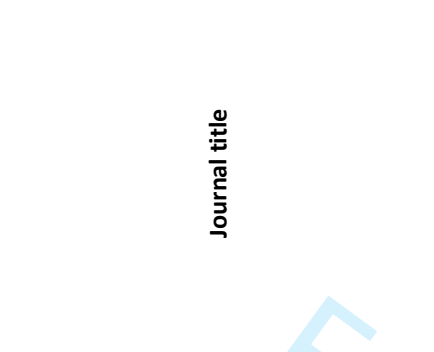 } & \multirow[b]{2}{*}{ 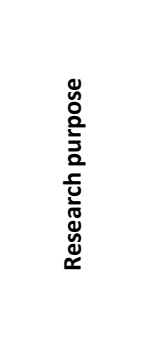 } & \multirow[b]{2}{*}{ 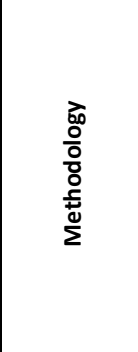 } & \multirow[b]{2}{*}{ 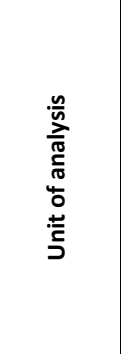 } & \multirow[b]{2}{*}{ 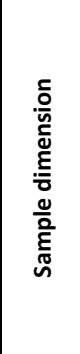 } & \multirow[b]{2}{*}{ 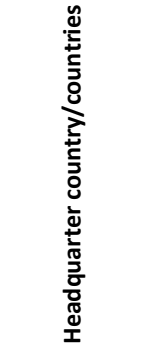 } & \multirow[b]{2}{*}{ 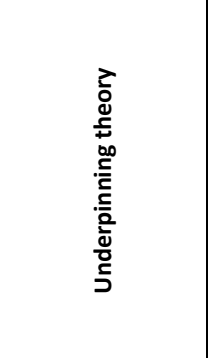 } & \multirow[b]{2}{*}{ 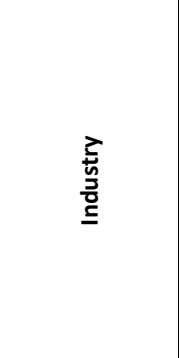 } & \multirow[b]{2}{*}{ 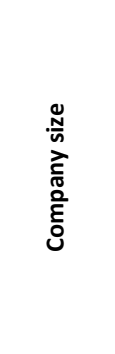 } & \multicolumn{3}{|c|}{ Antecedents } & \multirow[b]{2}{*}{ 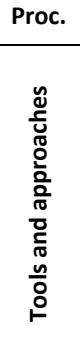 } & \multicolumn{2}{|c|}{ Consequences } \\
\hline & & & & & & & & & & & 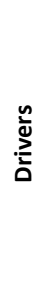 & 恣 & 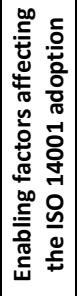 & & 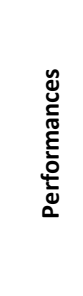 & 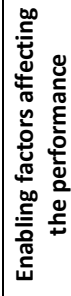 \\
\hline Prajogo et al. & 2014 & $\begin{array}{l}\text { International Journal of Operations \& } \\
\text { Production Management }\end{array}$ & $\begin{array}{l}\text { theory } \\
\text { building }\end{array}$ & survey & firm & 286 & Australia & $\begin{array}{c}\text { Theory of } \\
\text { Organizational } \\
\text { Climate }\end{array}$ & - & - & & & & & $\mathrm{x}$ & \\
\hline Reynolds and Yuthas & 2008 & Journal of Business Ethics & exploration & conceptual & - & - & - & - & - & - & $\mathbf{x}$ & & $x$ & $x$ & & \\
\hline Schoenherr & 2012 & $\begin{array}{l}\text { International Journal of Production } \\
\text { Economics }\end{array}$ & $\begin{array}{l}\text { theory } \\
\text { extention }\end{array}$ & survey & plant & 1211 & - & $\begin{array}{l}\text { Theory of } \\
\text { Performance } \\
\text { Frontiers, RBV }\end{array}$ & - & - & & & $\mathbf{x}$ & $\mathbf{x}$ & $\mathbf{x}$ & $\mathbf{x}$ \\
\hline Schoenherr and Talluri & 2013 & $\begin{array}{c}\text { IEEE Transactions on Engineering } \\
\text { Management }\end{array}$ & $\begin{array}{l}\text { theory } \\
\text { testing }\end{array}$ & survey & plant & 402 & Europe, US & $\begin{array}{c}\text { RBV, Institutional } \\
\text { Theory }\end{array}$ & $\begin{array}{l}\text { computing, } \\
\text { eletronics }\end{array}$ & medium & & $\mathbf{x}$ & $\mathrm{x}$ & & $\mathbf{x}$ & \\
\hline Su et al. & 2015 & Journal of Operations Management & $\begin{array}{l}\text { theory } \\
\text { testing }\end{array}$ & survey & firm & 101 & - & $\begin{array}{l}\text { Competitive } \\
\text { Dynamics }\end{array}$ & $\begin{array}{c}\text { Paper, } \\
\text { chemical, } \\
\text { machinery, } \\
\text { computer and } \\
\text { electronic, } \\
\text { transportation } \\
\text { equipment } \\
\end{array}$ & - & & & & & & $\mathbf{x}$ \\
\hline Sullivan & 2005 & Journal of Business Ethics & exploration & conceptual & - & - & Australia & - & $\begin{array}{l}\text { mining } \\
\text { industry }\end{array}$ & - & & $\mathbf{x}$ & & $\mathbf{x}$ & $\mathbf{x}$ & \\
\hline Testa et al. & 2012 & Ecological Economics & $\begin{array}{l}\text { theory } \\
\text { building }\end{array}$ & survey & firm & 156 & Italy & - & public sector & - & & & & & $\mathbf{x}$ & \\
\hline Testa et al. & 2018 & Journal of Business Ethics & $\begin{array}{l}\text { theory } \\
\text { building }\end{array}$ & survey & firm & 243 & Europe & $\begin{array}{c}\text { Neo- } \\
\text { Institutional } \\
\text { Theory, } \\
\text { Stakeholder } \\
\text { Theory } \\
\end{array}$ & & - & & $\mathbf{x}$ & & & & $\mathbf{x}$ \\
\hline Texeira et al. & 2012 & $\begin{array}{c}\text { International Journal of Production } \\
\text { Economics } \\
\end{array}$ & $\begin{array}{l}\text { theory } \\
\text { building }\end{array}$ & case study & firm & 9 & Brazil & - & - & large & $x$ & & & $x$ & $x$ & \\
\hline Tuppura et al. & 2016 & Business Strategy and the Environment & $\begin{array}{l}\text { theory } \\
\text { testing }\end{array}$ & survey & firm & 60 & - & - & forest industry & large & $\mathbf{x}$ & & & & & \\
\hline Vastag & 2004 & $\begin{array}{c}\text { Production and Operations } \\
\text { Management }\end{array}$ & exploration & simulation & - & - & - & - & - & - & $\mathbf{x}$ & & $x$ & & $x$ & \\
\hline Vastag and Melnyk & 2002 & $\begin{array}{c}\text { International Journal of Production } \\
\text { Research } \\
\end{array}$ & exploration & \begin{tabular}{|c|} 
survey, \\
case study
\end{tabular} & $\begin{array}{l}\text { individual } \\
+ \text { firm }\end{array}$ & $\begin{array}{l}\text { S:504 } \\
\text { CS: } 1 \\
\end{array}$ & US & - & - & - & $\mathbf{x}$ & $\mathbf{x}$ & $x$ & $\mathbf{x}$ & $\mathbf{x}$ & $\mathbf{x}$ \\
\hline Viadiu et al. & 2006 & $\begin{array}{c}\text { International Journal of Operations \& } \\
\text { Production Management }\end{array}$ & $\begin{array}{l}\text { theory } \\
\text { building }\end{array}$ & simulation & - & - & $\begin{array}{l}\text { Spain, UK, } \\
\text { Sapan, US }\end{array}$ & - & - & - & & & $\mathbf{x}$ & & & \\
\hline Wiengarten et al. & 2017 & Production Planning and Control & $\begin{array}{l}\text { theory } \\
\text { building }\end{array}$ & survey & plant & 59 & Ireland & - & - & - & & & & & $\mathbf{x}$ & $\mathrm{x}$ \\
\hline
\end{tabular}




\begin{tabular}{|c|c|c|c|c|c|c|c|c|c|c|c|c|c|c|c|c|}
\hline \multirow[b]{2}{*}{$\begin{array}{l}\bar{n} \\
\frac{n}{0} \\
\frac{c}{5} \\
\frac{3}{4}\end{array}$} & \multirow[b]{2}{*}{ 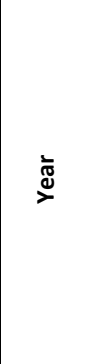 } & \multirow[b]{2}{*}{ 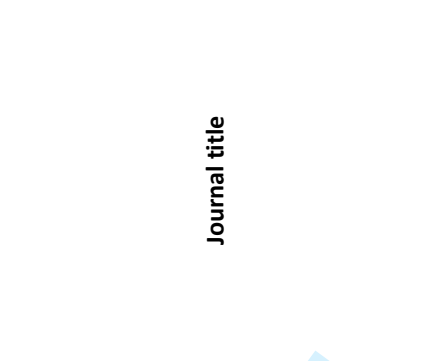 } & \multirow[b]{2}{*}{ 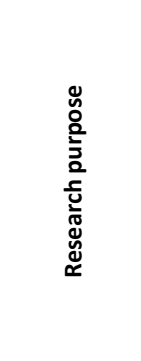 } & \multirow[b]{2}{*}{ 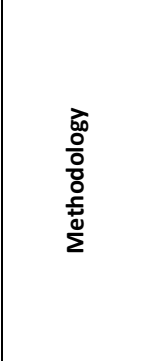 } & \multirow[b]{2}{*}{$\begin{array}{l}\frac{n}{n} \\
\frac{n}{\pi 0} \\
\frac{5}{\pi} \\
\frac{0}{0} \\
0 \\
5 \\
5\end{array}$} & \multirow[b]{2}{*}{ 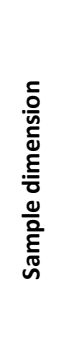 } & \multirow[b]{2}{*}{ 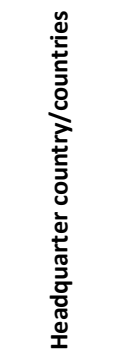 } & \multirow[b]{2}{*}{ 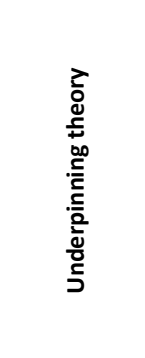 } & \multirow[b]{2}{*}{ 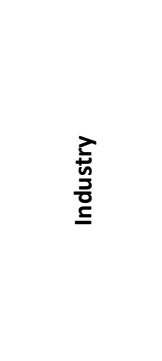 } & \multirow[b]{2}{*}{ 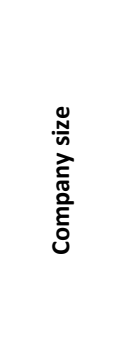 } & \multicolumn{3}{|c|}{ Antecedents } & \multirow[b]{2}{*}{ 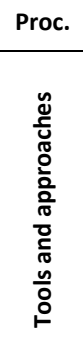 } & \multicolumn{2}{|c|}{ Consequences } \\
\hline & & & & & & & & & & & 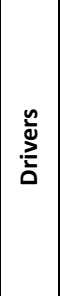 & 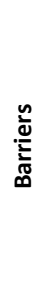 & 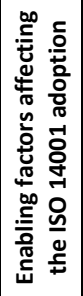 & & 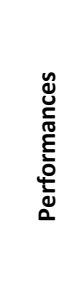 & 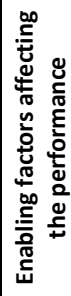 \\
\hline Xu et al. & 2016 & Business Strategy and the Environment & $\begin{array}{l}\text { theory } \\
\text { building }\end{array}$ & simulation & firm & 173 & China & $\begin{array}{l}\text { Signaling } \\
\text { theory }\end{array}$ & - & - & & & & & $\mathbf{x}$ & \\
\hline Zailani et al. & 2012 & $\begin{array}{l}\text { International Journal of Operations \& } \\
\text { Production Management }\end{array}$ & $\begin{array}{l}\text { theory } \\
\text { testing }\end{array}$ & survey & firm & 132 & Malaysia & $\begin{array}{l}\text { Institutional } \\
\text { Theory, } \\
\text { Stakeholder } \\
\text { Theory, } \\
\text { Strategic } \\
\text { Choice } \\
\text { Theory } \\
\end{array}$ & - & $\begin{array}{l}\text { medium } \\
\text { and large }\end{array}$ & $x$ & & & & $\mathbf{x}$ & $x$ \\
\hline Zhu et al. & $2012 a$ & Ecological Economics & $\begin{array}{l}\text { theory } \\
\text { building }\end{array}$ & survey & firm & 377 & China & $\begin{array}{c}\text { Neo- } \\
\text { Istitutional } \\
\text { Theory }\end{array}$ & $\begin{array}{l}\text { Chemical, } \\
\text { electronic, } \\
\text { automotive } \\
\text { pharmaceutic }\end{array}$ & - & $x$ & & & $x$ & & \\
\hline Zhu et al. & $2012 b$ & Production Planning \& Control & exploration & conceptual & - & - & China & $\begin{array}{l}\text { Diffusion of } \\
\text { Innovation }\end{array}$ & - & - & $x$ & $\mathbf{x}$ & $x$ & & & \\
\hline Zutshi and Sohal & $2004 a$ & Technovation & exploration & survey & firm & 286 & $\begin{array}{l}\text { Australia, } \\
\text { New } \\
\text { Zeland }\end{array}$ & - & - & $\begin{array}{l}\text { stratified } \\
\text { sample }\end{array}$ & $x$ & $x$ & $\mathrm{x}$ & $\mathbf{x}$ & $\mathbf{x}$ & \\
\hline Zutshi and Sohal & $2004 b$ & Technovation & exploration & survey & firm & 286 & $\begin{array}{l}\text { Australia, } \\
\text { New } \\
\text { Zeland } \\
\end{array}$ & - & - & $\begin{array}{l}\text { stratified } \\
\text { sample }\end{array}$ & $\mathbf{x}$ & $\mathrm{x}$ & & $\mathbf{x}$ & $\mathbf{x}$ & \\
\hline & & & & & & & & & TOTAL & & 38 & 22 & 38 & 36 & 51 & 25 \\
\hline
\end{tabular}

